\title{
Characterization and Pathology of Pyroclastic Stones in the Cut Rock Historical Architecture of Kandovan Village
}

\author{
F. AMINI BIRAMI ${ }^{a}$, M. RAZANI ${ }^{b *}$, E. ASGHARI KALJAHI ${ }^{a}$, S. M. A. EMAMI ${ }^{b}$ and A. \\ BAGHBANAN $^{c}$ \\ ${ }^{a}$ Faculty of Natural Science, Department of Geology, University of Tabriz, IRAN \\ ${ }^{b}$ Faculty of Conservation, Department Conservation-Restoration of Historic-Cultural Properties, Art \\ University of Isfahan, IRAN \\ ${ }^{C}$ Faculty of Mining Engineering, Department of Mining Engineering, Industrial University of Isfahan, IRAN
}

\begin{abstract}
Tandovan historical village, in the vicinity of Osku town is one of the most important attractive Zsites in East Azerbaijan province which is outstanding and prominent due to the hewn-cut house of rock skirt of the Sahand volcano. This site has been registered in 1998 on the national cultural heritage list of Iran. Kandovan rocky architecture, from geological point of view, is on the surfaces of a thick ignimbrite layer that this layer, due to natural weathering and erosion along the main joints and discontinuities of Kandovan valley, has created conical forms and structures. According to the existing theory, Kandovan village was inhabited and settled in these conical buildings since the Ilkhanid era. Recent developments on rock decay in rock-cut architecture of the Kandovan historical village, have heightened the need for recognizing the role of different factors of weathering process on this site. Therefore, the main objective of this study was to assess the effect of inherent vice as a fundamental factor in deterioration patterns. For this purpose, field and laboratory investigations like sampling and observation, characterization with thin section petrography and X-ray diffraction analyzes, along with the measurement of physical properties and durability of rock in rocky houses, the role of inherent vice rock with intensity of rock mass Kandovan weathering has been done. Nowadays, intensity of decay and weathering in Kandovan village rocks causes of poor living conditions, ruination, and seasonal residence or nonresidential conditions. Based on the rock characterization, water absorption, dry density, total porosity content, saturation coefficient, slake durability and experiment for resistance to freezing-thawing demonstrated that Kandovan ignimbrite rock have poor durability and high sensitive to predisposing factors to deterioration such as wetting and drying and freezing-thawing cycles. The collection of these inherent properties causes of the internal structure to be non-resistance to the tensions arising from the impact of climate cycles. The local climate could be considered (or suggested) as the main reason of weathering and erosion of this rocky architecture.
\end{abstract}

Keywords: Decay, Weathering, Inherent Vice, Rock-Cut Architecture of Kandovan village, Ignimbrite

* _ Corresponding author: m.razani@aui.ac.ir 


\title{
تحليل ساختارشناسى سنََهاى آذر آوارى در معمارى صخره كند
}

\section{روستاى تاريخى كندوان}

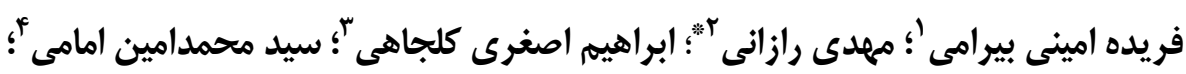

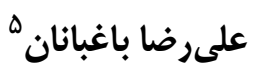

\author{
I. دانش آموخته كارشناسى ارشد زمينشناسى زيستمحيطى، دانشكاه تبريز، ايران.
}

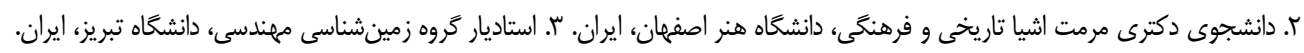

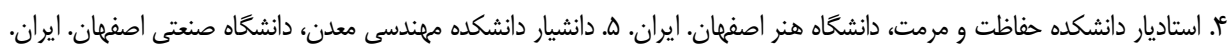

جكيده

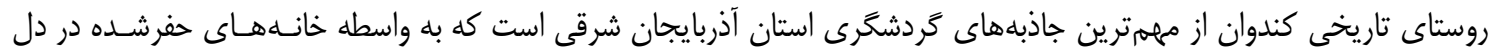

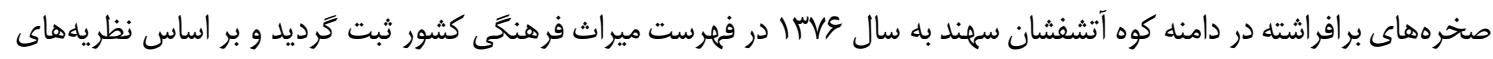

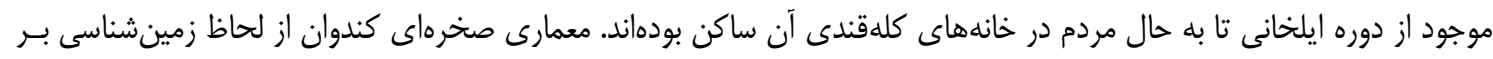

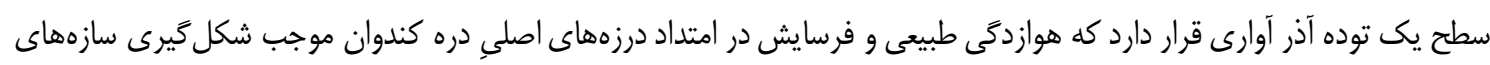

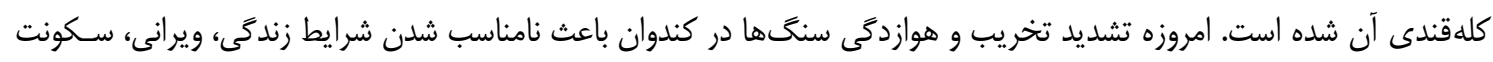

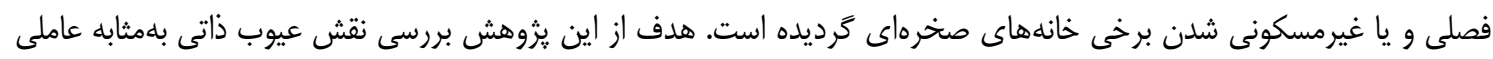

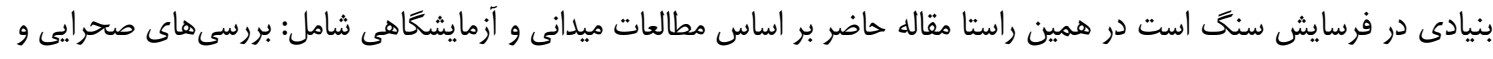

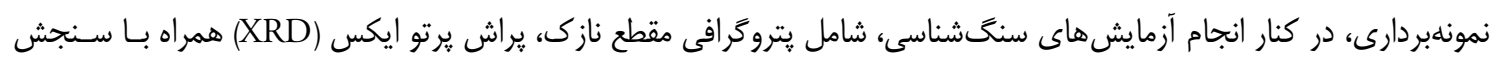

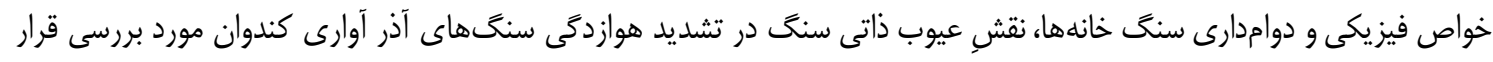

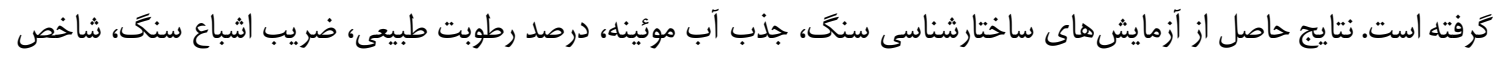

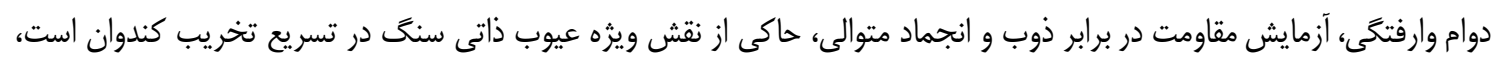

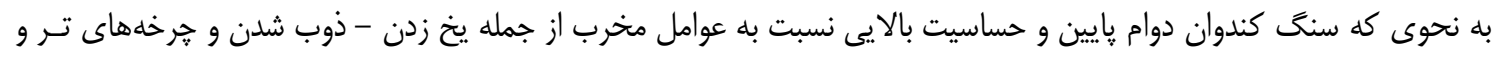

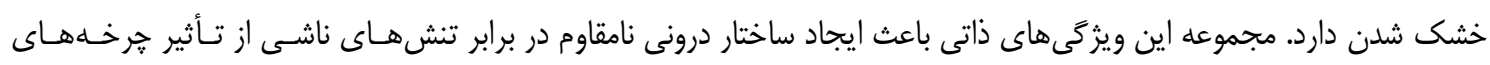

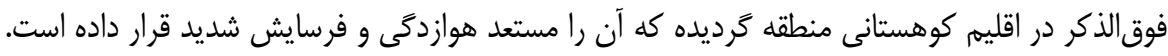

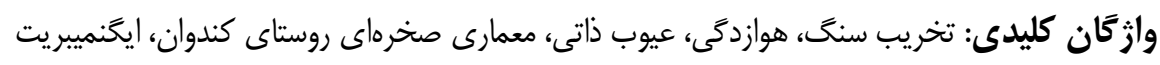

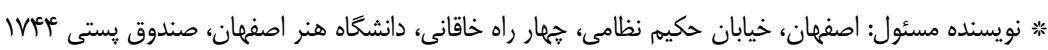

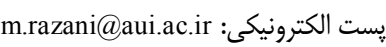
C) حق نشر متعلق به نويسنده(كان) است و نويسنده تحت مجوز Creative Commons Attribution License به مجله اجازه مىدهد مقاله خاب شده را با ديخران به اشتراك بكذارد منوط بر اينكه حقوق مؤلف اثر حفظ و و به به انتشار اوليه مقاله در اين مجله اشاره شود. 
مرمت اين سازههاى سنكَى در رأس اولويتهاى برنامـهـ مديريتى كلان روستا قرارگرفتـهـ اسـت. تحقيـق حاضـر بخشى از طرح كلانِ مطالعات حفاظت و مرمت، معمارى صخرهاى روستاى تاريخى كندوان با بررسى ويزَى هناى

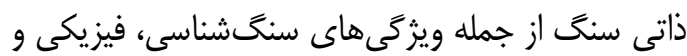

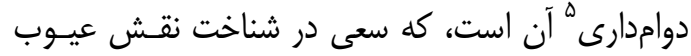

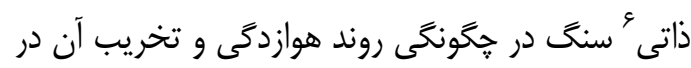
قالب مطالعات ساختارشناسى و آسيبشناسى دارد.

\section{r- بح روش تحقيق}

تحقيق ييش رو به روش تحليلى - تجربى و بر مبنـاى

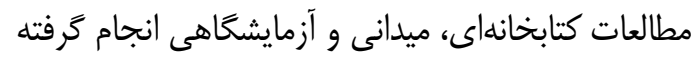

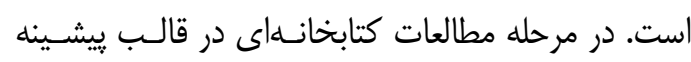

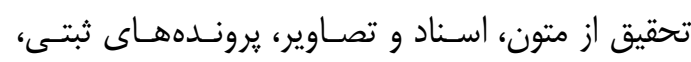

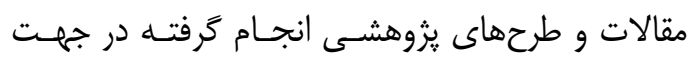

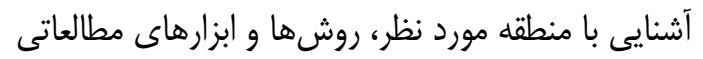

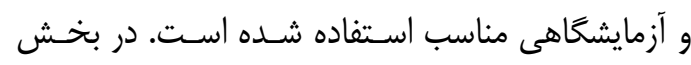

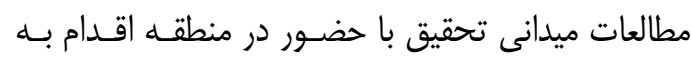

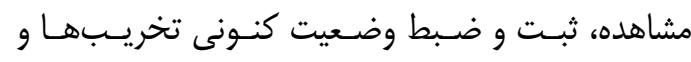

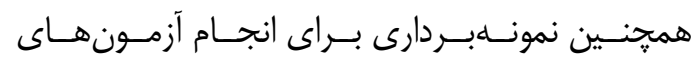

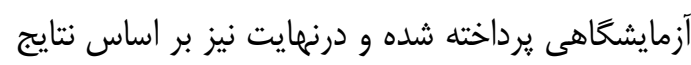

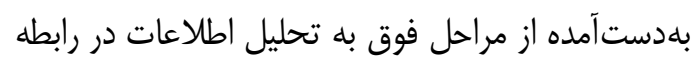
با موضوع مورد بحث اقدام شده است.

\section{r- بيشينه تحقيق}

روستاى كندوان (شكل ()، در ادامه دره ويسدهر (اسـكو

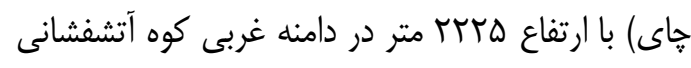

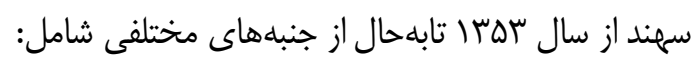

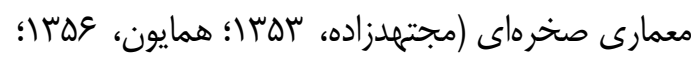

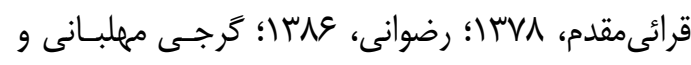

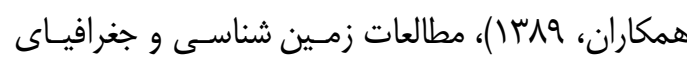

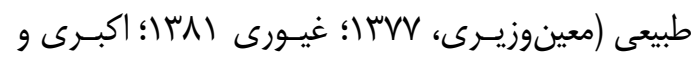

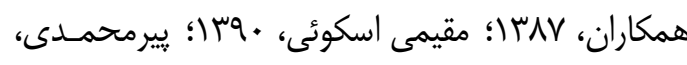

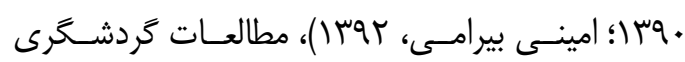

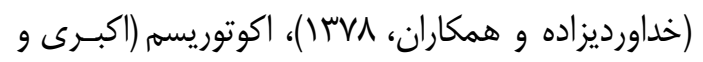

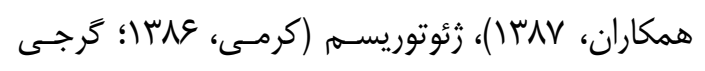

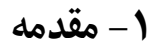

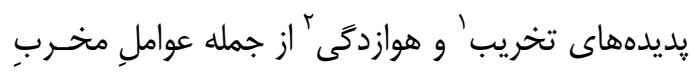

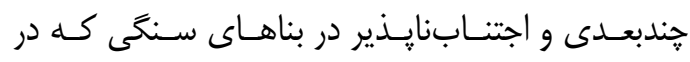

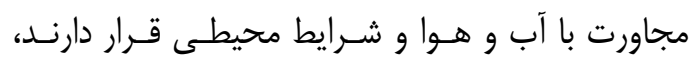

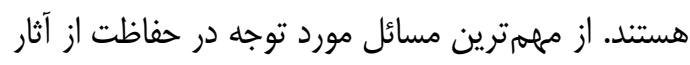

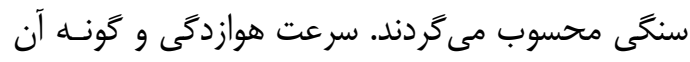

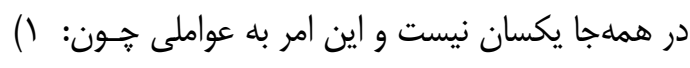

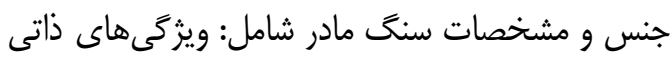
هماند تركيب كانى شناختى، بافت و ساخت آن كـه در

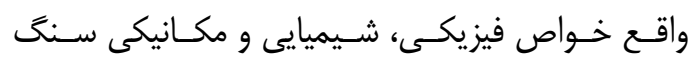

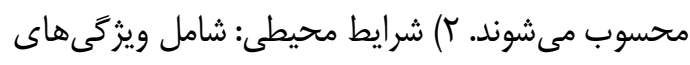

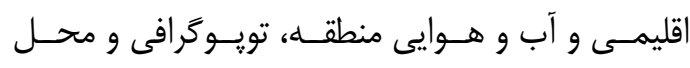

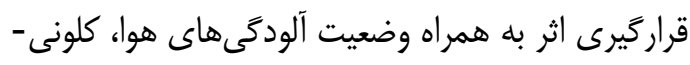

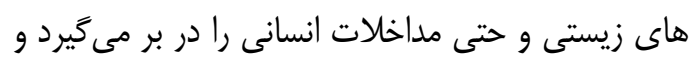

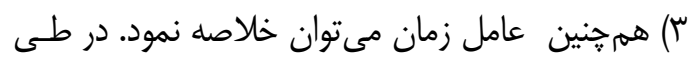

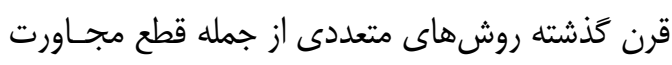

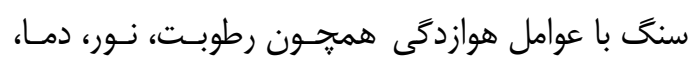

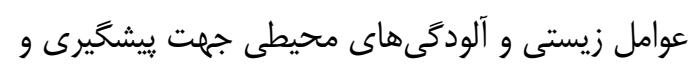

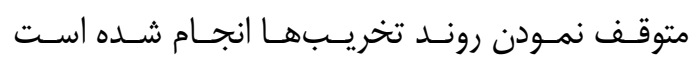
(Doehne et al., 2010: 5)

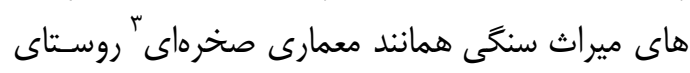

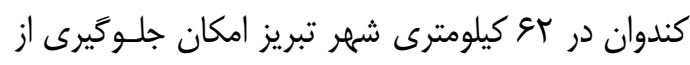

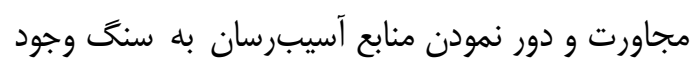

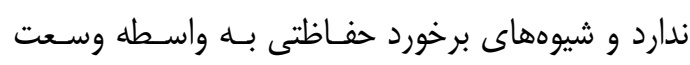
محل و ملاحظات زيستمحيطى مربـوط بـ بـهـ سـكونت

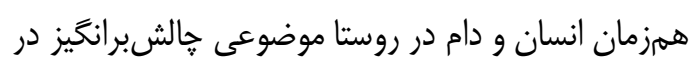

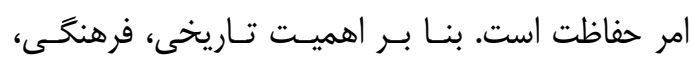

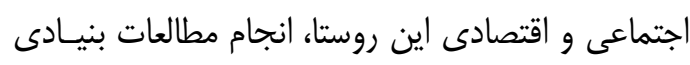

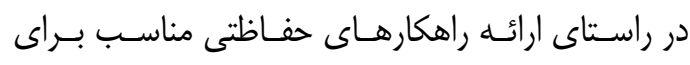

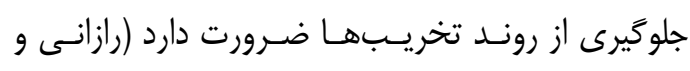

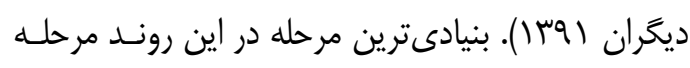

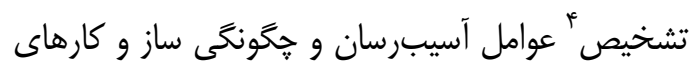

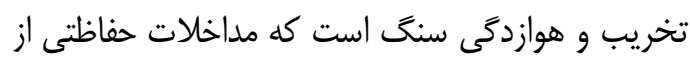

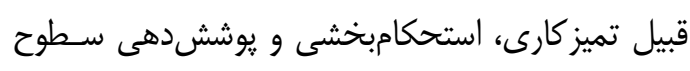

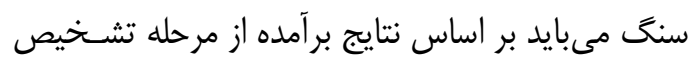

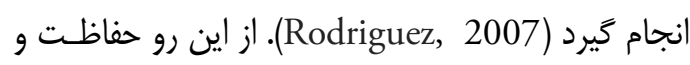


آسيبشناسى سنخَهـاى معمـارى صـخرهاى روسـتاى

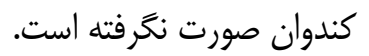

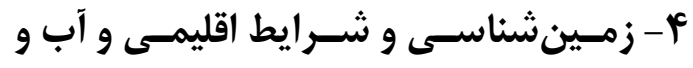
هوايى كندوان

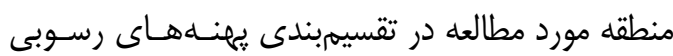
ساختارى ايران در بهنه ايران مركزى قرار دارد (آقانباتى،

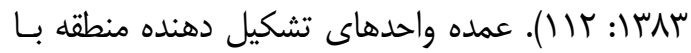
توجه به نقشه زمينشناسى ...... (1: اسكو (شكل r)

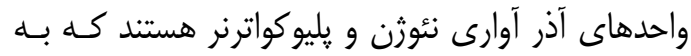

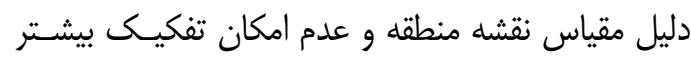

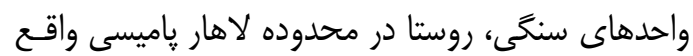

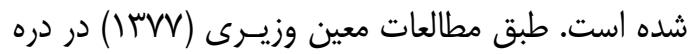

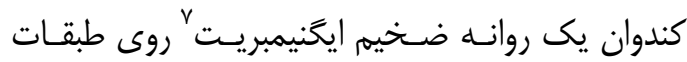
برش آتشفشانى قرار كرفته كه توسـط آكَلـومرا و روانـهـ

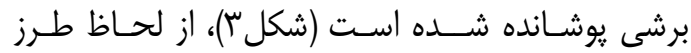
تشكيل ايحتيمبريتها اين كَونه عنوان شــه اسـت كهه،
مهلبانى و همكاران، MMM (IM)، و مطالعات طـرح هـادى و

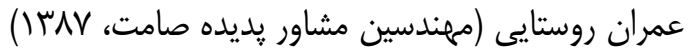

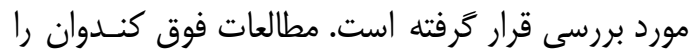

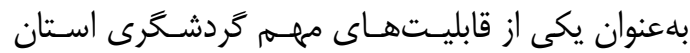
آذربايجان شرقى و شمال غرب كشور معرفى نمودهانــــان.

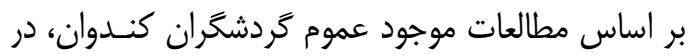
درجه نخست براى ديدن خانههاى كلدقنـدى، معمـارى صخرهاى و در ادامه براى استفاده از مناظر طبيعى و آب دئ دان معدنى روستا به اين محل مسافرت مى كنند (خداورديزاده

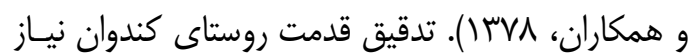

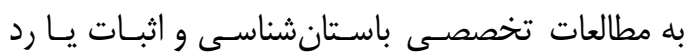
نظريات موجود دارد. با توجه به مستندترين نظريه موجود

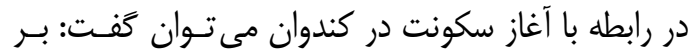

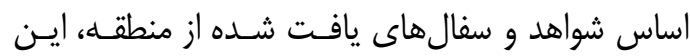

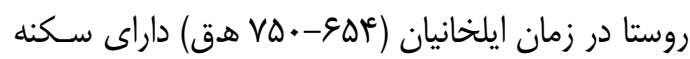

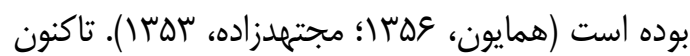

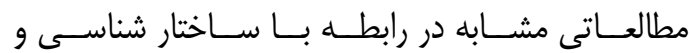

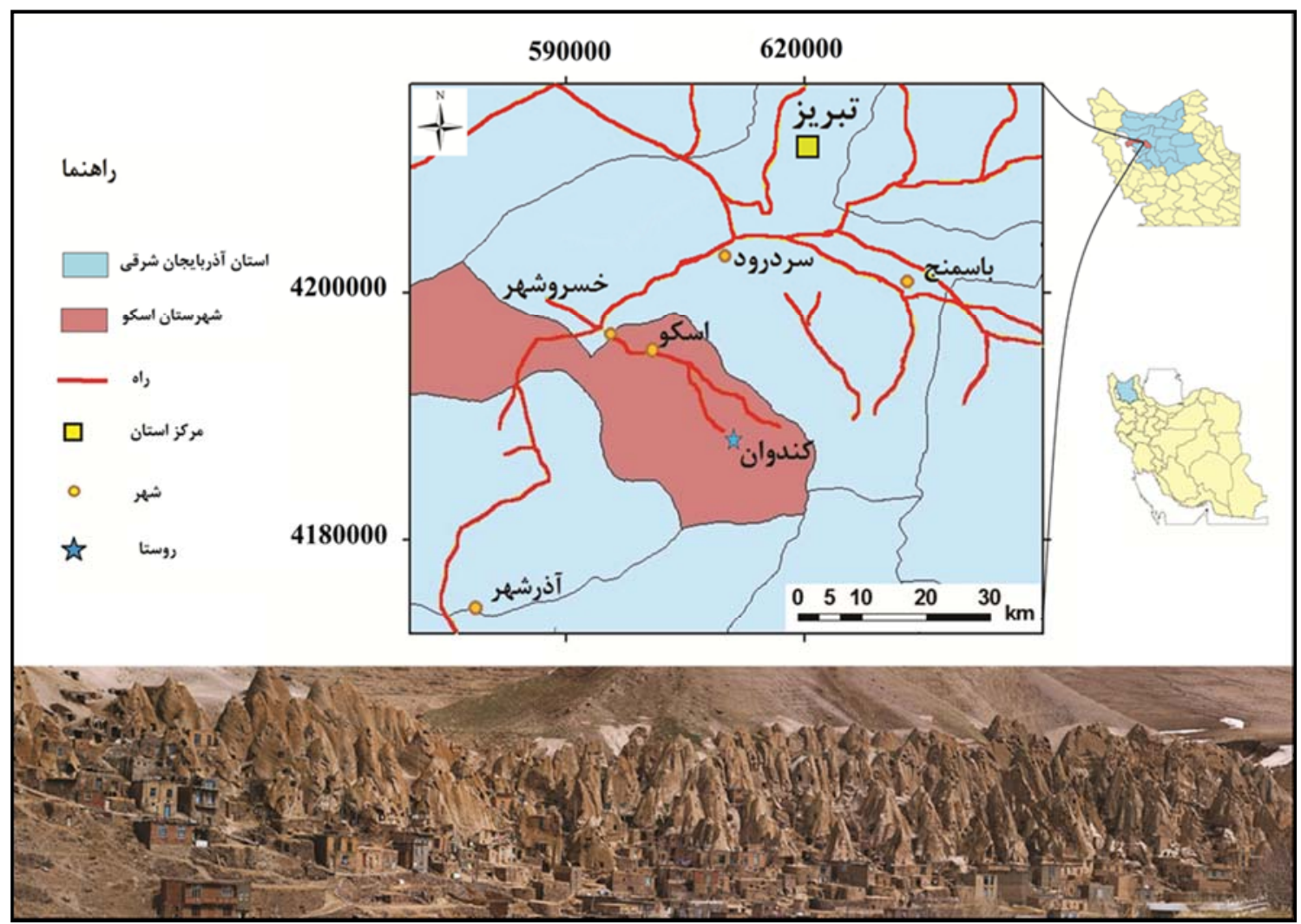

شكل ا: نقشه موقعيت و راههاى دسترسى به روستاى كندوان و منظر فرهنگى آن از ديد جنوبى.

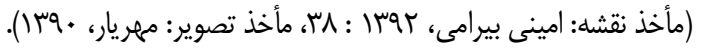




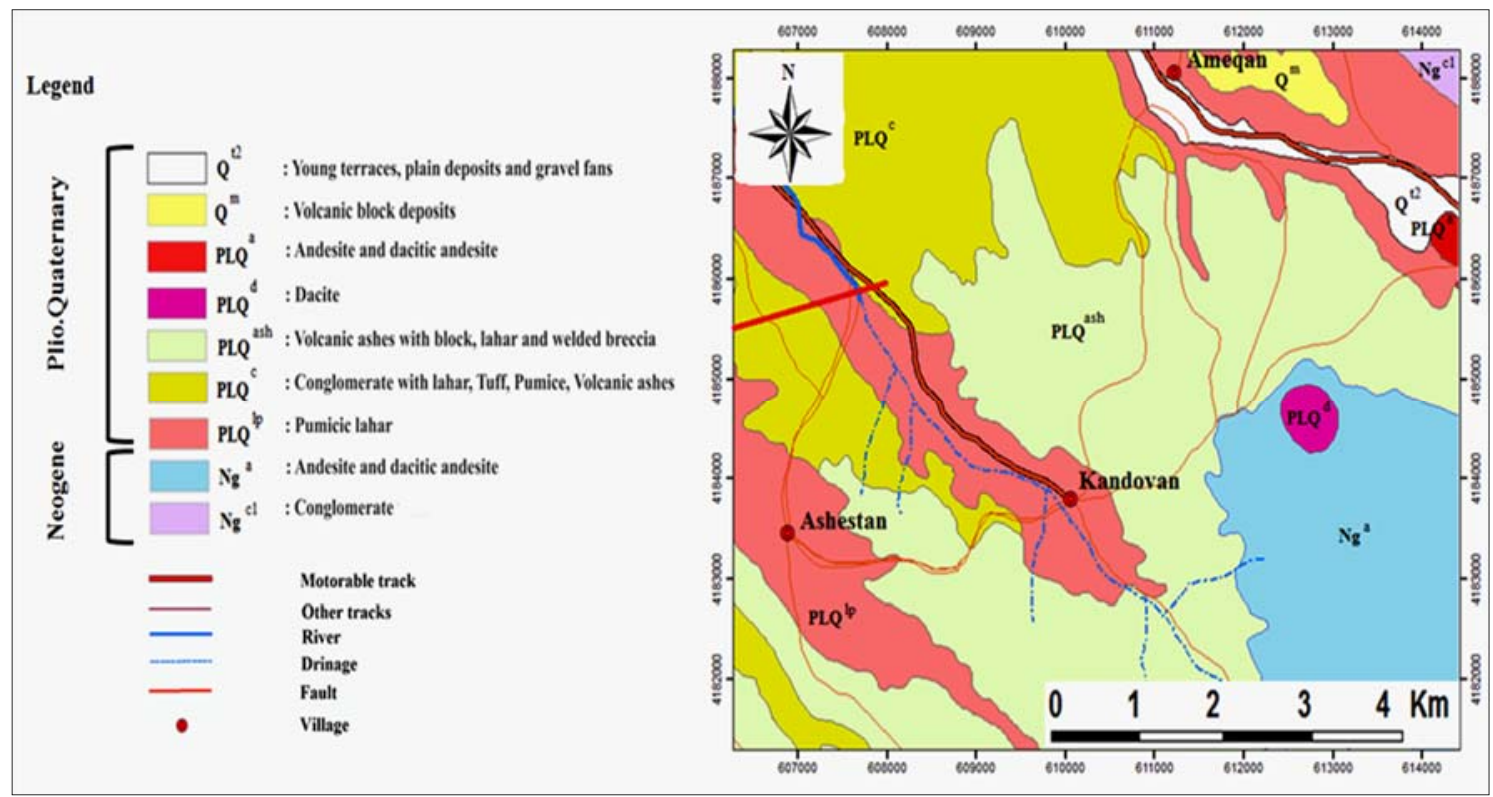

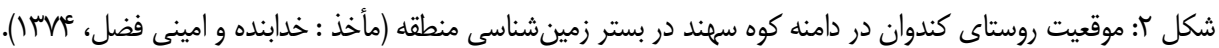

نحوى كه توجه به اقليم محلى و شناخت آن در راستاى تحليل مكانيسمهاى تخريب، هـوازدگى و همـين طـور براى بيشبينى شدت يديدهها و انجام اقدامات ييشخيرانه حفاظتى امرى ضرورى است. بلهنظور مطالعـه اقلـيم و شرايط آب و هوايى منطقه از اطلاعـات هواشناسى ده ده

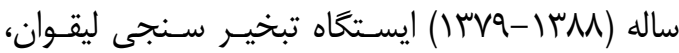
سازمان هواشناسى اسـتان آذربايجـان شـرقى اسـتفاده

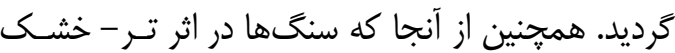

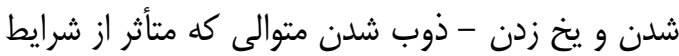
آب و هوايى منطقه است دهار تنشهاى حرارتى مكرر و و دون در نتيجه فروياشى مى شوند، از نمودارهاى دما و بـارش روزانه براى تخمين تعداد جرخههاى سالانه استفاده شده

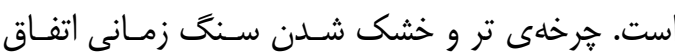

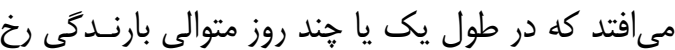

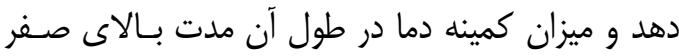

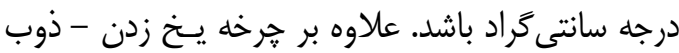

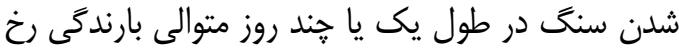

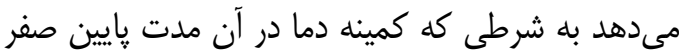
درجه سانتى گراد باشد كه در اين شرايط آب بارندكى كه كهينه

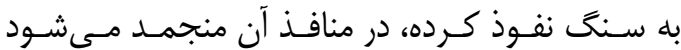

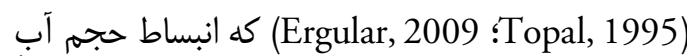
جذبشده باعث ايجاد تنش در منافذ، تركها و لايههـا

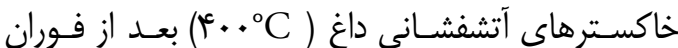

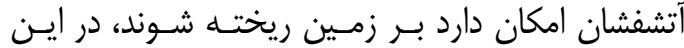

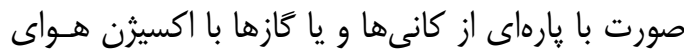
محبوس در خلل و فرج خاكستر تركيـب شـده و عمـل

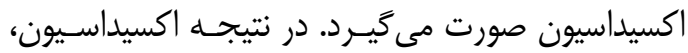

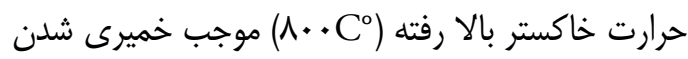

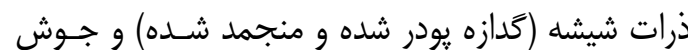
خوردن اين ذرات به يكــيخر مسىشـود. در ايـن حالـت

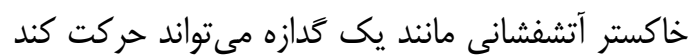

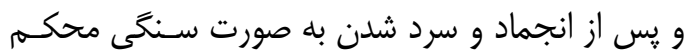

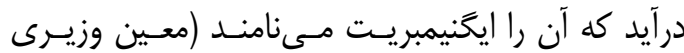

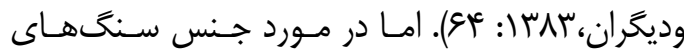

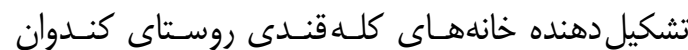
ابهاماتى وجود دارد. در مورد مراحل شكل گيرى اشـكال

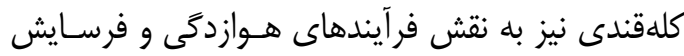

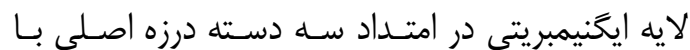

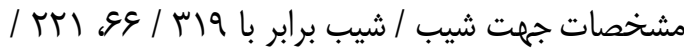

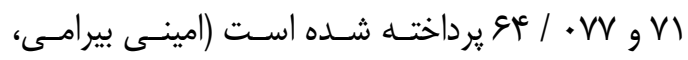

. (1. : : Irat شرايط اقليمى منطقه كه متأثر از زمسينشناسى و

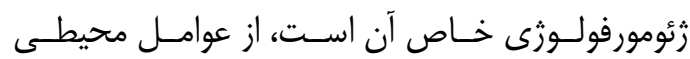

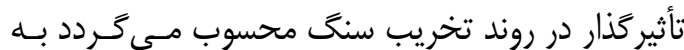

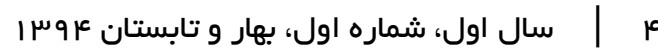



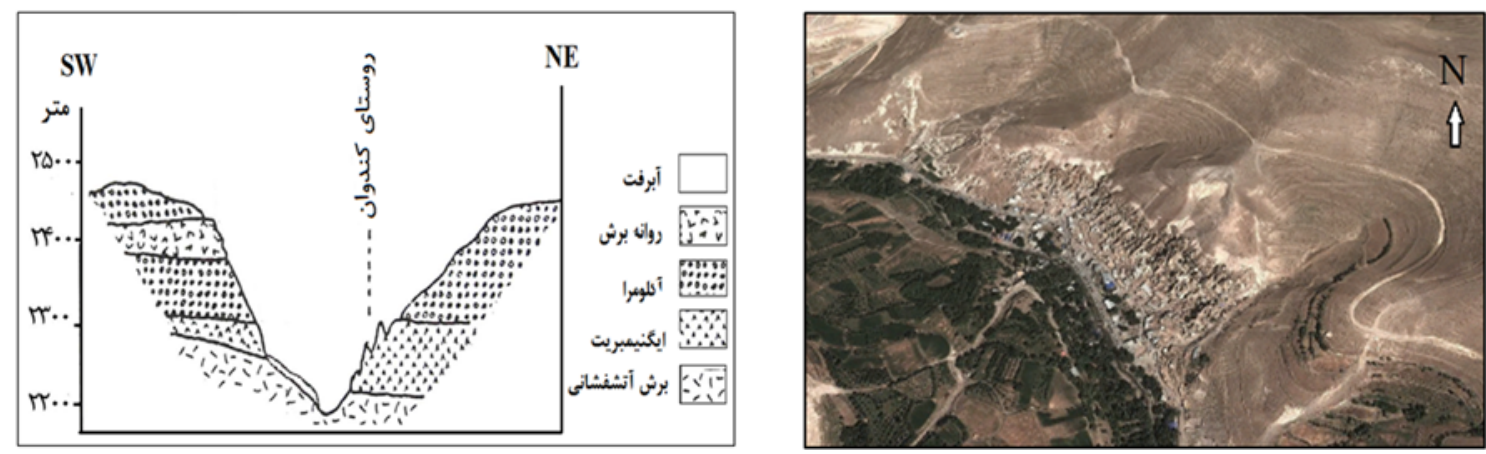

شكل ": الف) تصوير هوايى از دره و روستاى كندوان. ب) محل قراريّيرى روستا درميان لايههاى مقطع زمينشناسى دره كندوان.

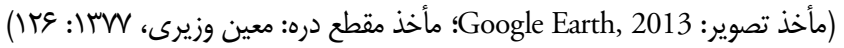

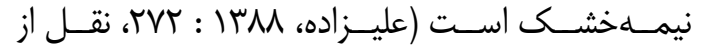
Emberger 1930

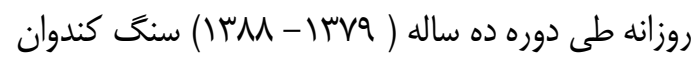

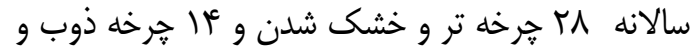

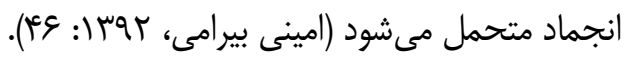

\section{ه- - مواد و روشها}

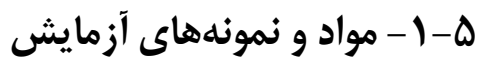

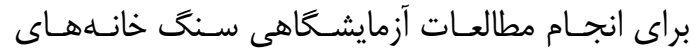

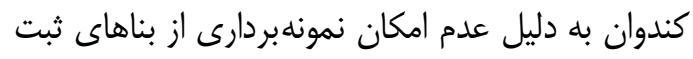

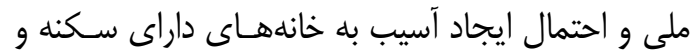

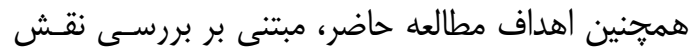

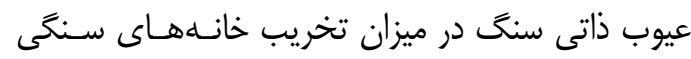

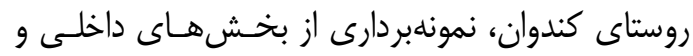
سالم مخروطهاى فاقد سكنه و در حال حفارى در بخش إنش

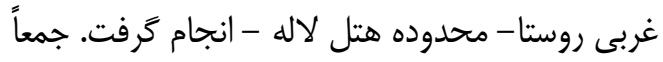

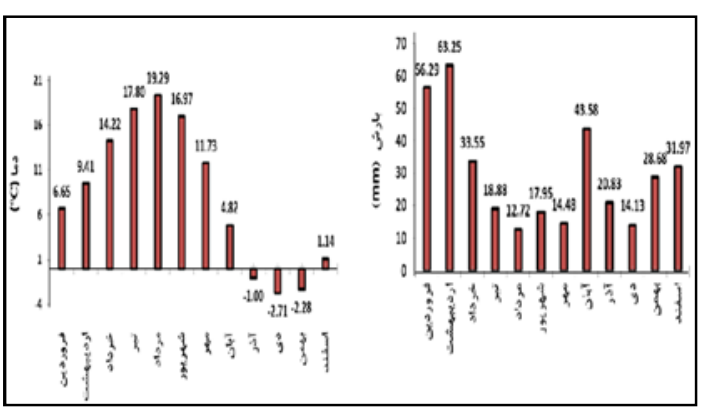

شكل أ: نمودار ميزان بارش و درجه حرارت متوسط ماهانه براى

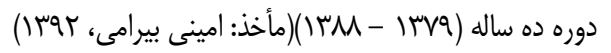

مى گردد. نتيجه اين يديده جــايش سـطوح بيرونسى در

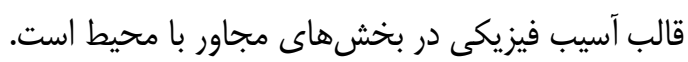

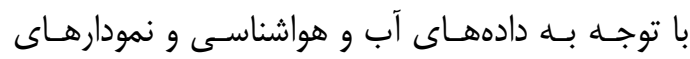
حاصل حداكثر ميزان بارش منطقه در ارديبهشت ماه برابر دارئ

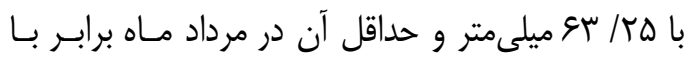

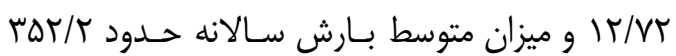

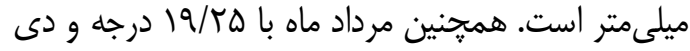

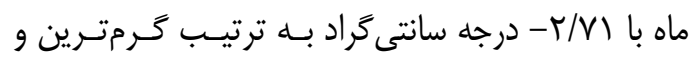
سردترين ماههاى سال هستند (شكل عأ).

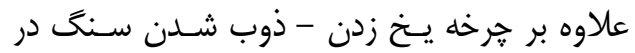

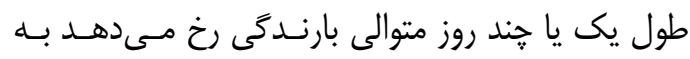

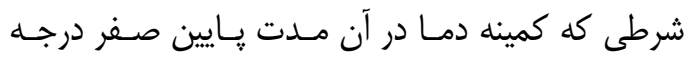

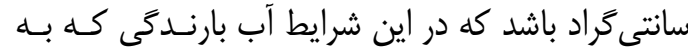

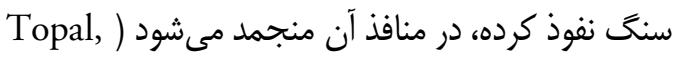

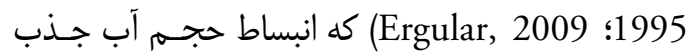

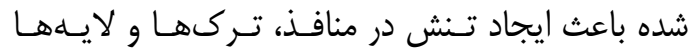

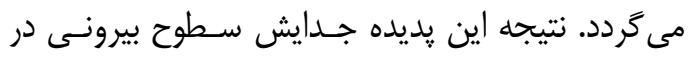

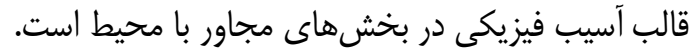
با توجه به دادهاى آب و هواشناسى و نمودارهـاى ديخ دماى

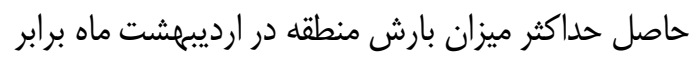

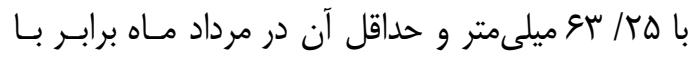
ما

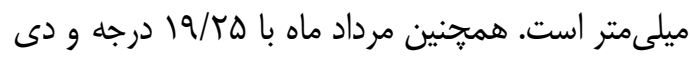

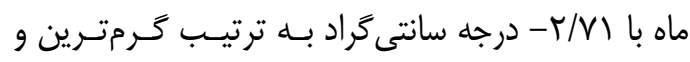
سردترين ماههاى سال هستند (شكل عأ). منطقه كندوان

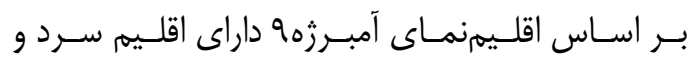




\begin{tabular}{|c|c|c|c|}
\hline \multicolumn{4}{|c|}{ جدول ا - أزمونهاى أزمايشكاهى، اهداف و مراجع استانداردها (ماخذ: نكارندكان) } \\
\hline استانداردها و تجهيزات & هدف & كونه أزمايشى & أزمونها \\
\hline 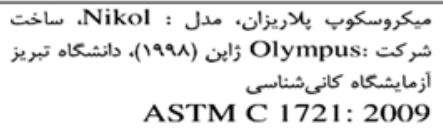 & شوجاخت كانى هام كذارى روابط بين دانهاى و بافت & (يتزوكر شنى مقطع نازى) & 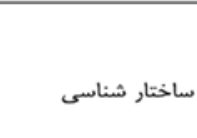 \\
\hline 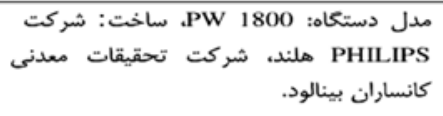 & تعيين فازهاى كريستالى موجود در نمونه & براش برتو ايكس (XRD) & \\
\hline ASTM D1585, 2004 & تعيين نرخ جذب أب سنك & نرخ جذب آب" & \multirow{4}{*}{ ويزگىهاى فيزيكى } \\
\hline ISRM, 1979 & رفتار آن درصد رطوبت سنك براى بيشبينى & درصد رطوبت طبيعى هـا & \\
\hline ISRM, 1979 & 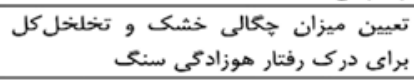 & جكالى خشك و تخلخل كل & \\
\hline TS 699,1987 & تعيين مقاومت سنك در برابر يخبندان & ضريب اشباع منكـ" & \\
\hline ASTM D 4644, 2004 & تعيين شاخص دوام در برابر هوام وارفتكى براى برأورد & شاخص دوام وارفتكى" & \multirow{3}{*}{ 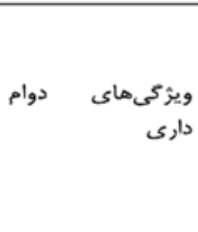 } \\
\hline ASTM D 5312, 2004 & شررسى دتوالى سنك در برابر يخ زدن و ذوب & ذوب شدن متوالى دوب، برابر يخ زدن و & \\
\hline ASTM D 5312, 2004 & شدرسى متوالى دوام سنك در برابر تر و خشك & متوالى د. برابر تر و خشك شدن & \\
\hline
\end{tabular}

هوازدگى شيميايى و فيزيكى را مىتوان از اين روشهـا

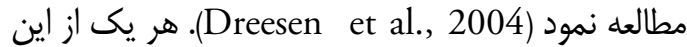

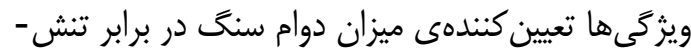
هاى وارده، همجيون تنشهاى حرارتى، فشـار روبـاره،

$$
\text { فرسايش و غيره هستند. }
$$

\section{- مطالعه مقاطع نازك ميكروسكويى}

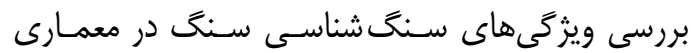

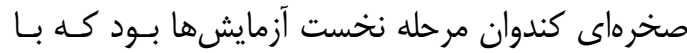
تهيه مقطع ناز كى از جهات مختلف سنگ بر بر أ نمونسهى حاصله از بررسىهاى ميدانى صورت كرفت كـه مقـاطع نارك

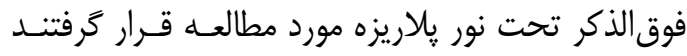

$$
\text { ( شكلهاى (V-9). }
$$

\section{ه-f - ويزَّى هاى فيزيكى و دوامدارى}

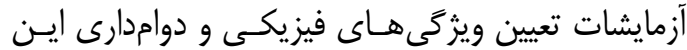
امكان را فراهم مى كند تا عوامل ذاتى، مـؤثر در ميـزان

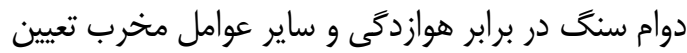
شود. از آنجا كه هيج آزمايشى به تنهايى نمى تواند رفتار

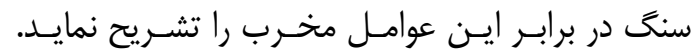
بنابراين تركيبى از آزمايشات مورد استفاده قرار مى كيـيرد

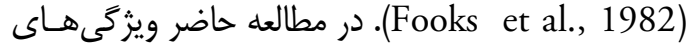

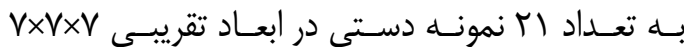
سانتىمتر براى مطالعات انتخاب و به آزمايشخاه انتقـال

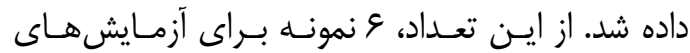

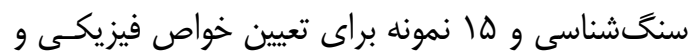
دوامدارى سنگ مورد استفاده قرار كرفته است.

ه- - - - مطالعات آزمايشخاهى

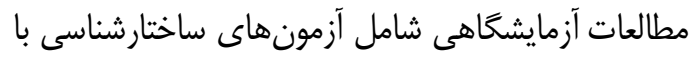

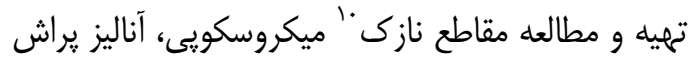

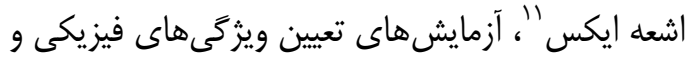
دوامدارى نمونهها بر اساس استاندارهاى ملى و بينالمللى إنى به انجام رسيده است (جدول ().

ه-" - ساختار شناسى و سنَگشناسى

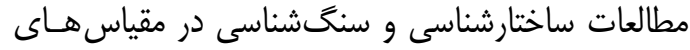

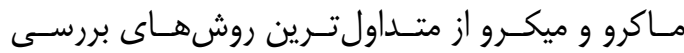
ويزگى هاى ذاتى سنگ هستند و مواردى جـون تركيـب

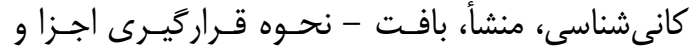
كانىهاى سنگ در كنار يكديكر، درصد كانىهـا، ابعـاد

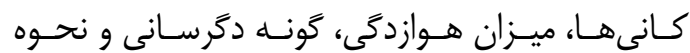

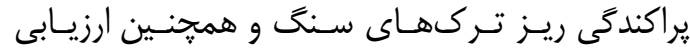

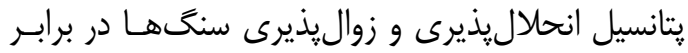


لحليل ساختارشناسى سنكَهاى آذرآوارى در معمارى صخرهكند روستاى تاريخى كندوان
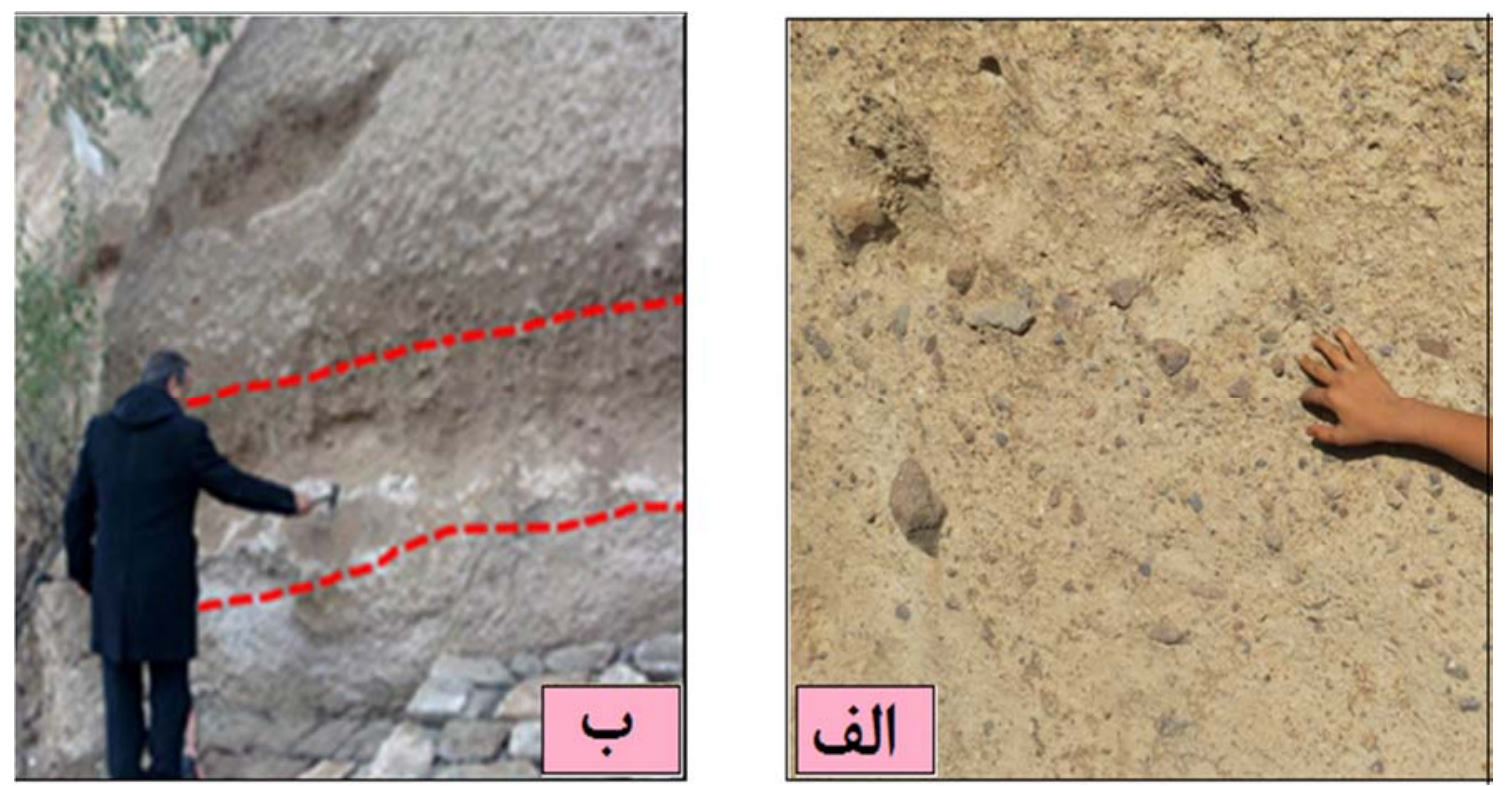

شكل ه: الف) توده سنگ و ب) ميان لايههاى فرسايش يافته در توده سنگ روستاى كندوان (ماخذ: نغارندكان بوسج)
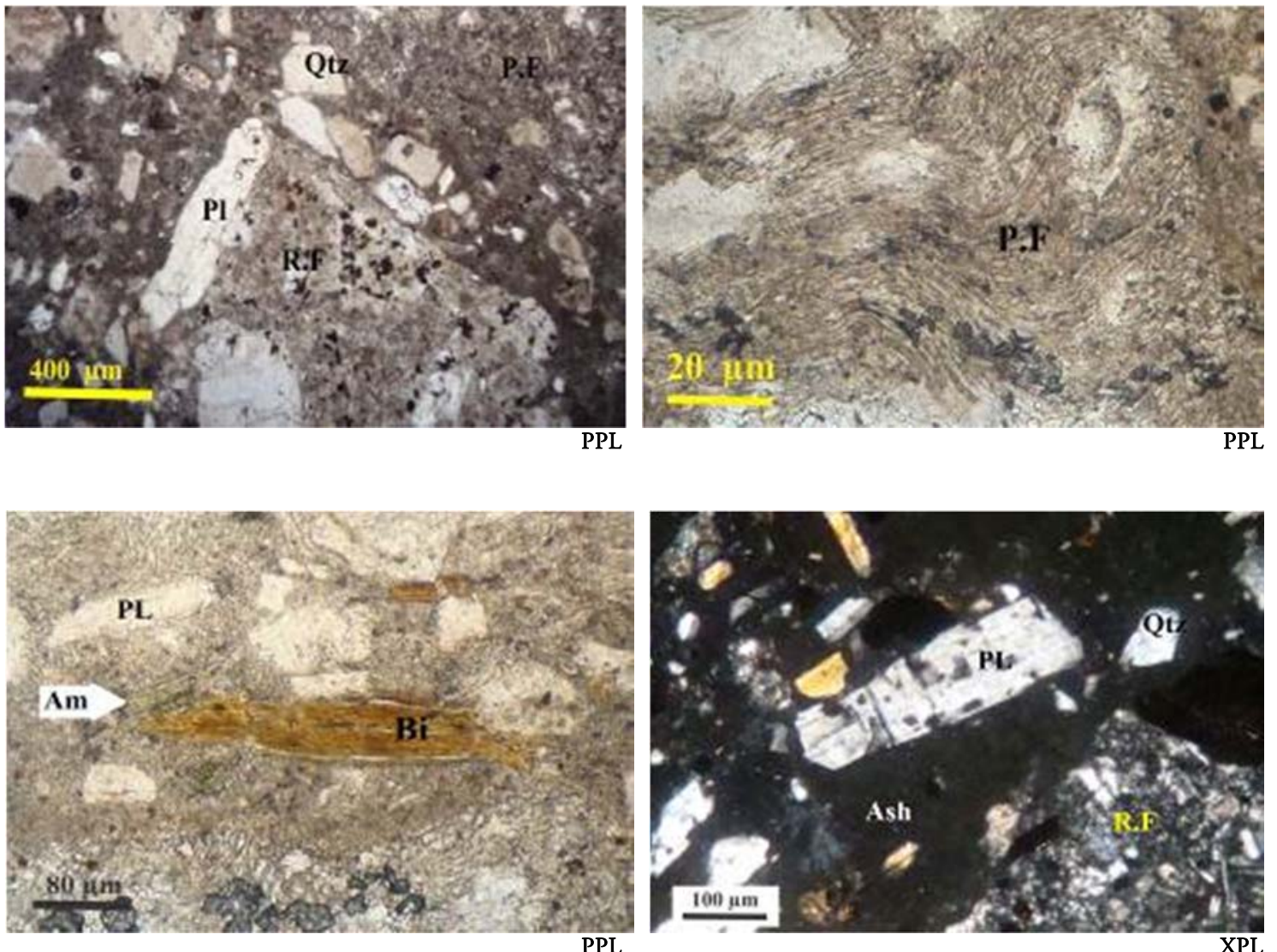

شكل و: تصاوير مقاطع ميكروسكويى از سنى كندوان(مأخذ: نغارندگان)

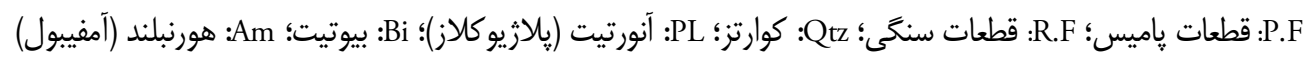




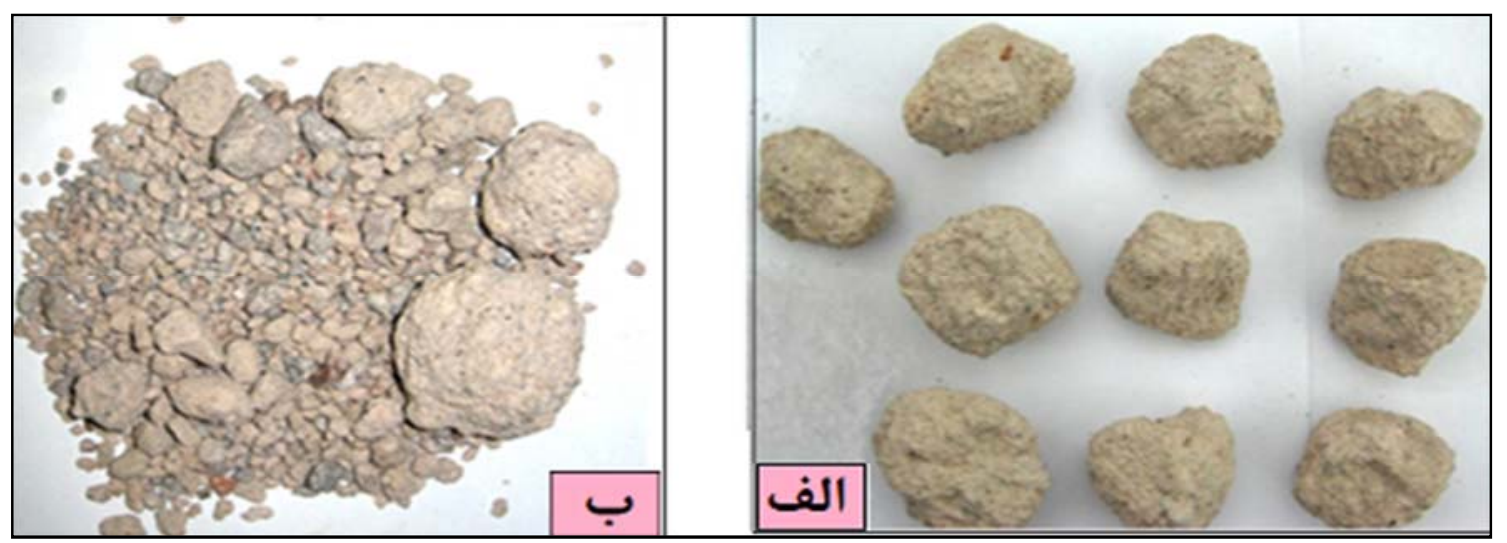

شكل V: تغييرات نمونهها در حين انجام آزمايش دوامدارى. (الف) نمونههاى اوليه و قبل از آزمايش، (ب) نمونهها بعد از مرحله دوم آزمايش. (مأخذ : نغارندكان)

حسب درصد را گويند. رطوبت موجود در سنى به علـت

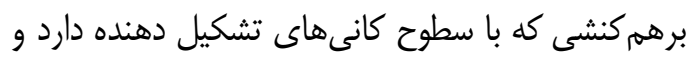
تغييراتى كه در مشخصات اين سطوح و طبيعـت ييونسد

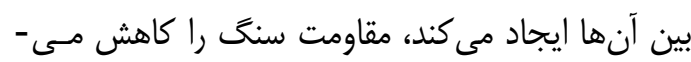
دهد. اين كاهش ممكن است به سبب افزايش فشار آب

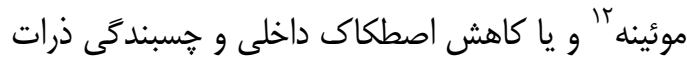
باشد. از طرفى واكنشهاى شيميايى كه بين آب و سنى اتفاق مىافتد باعث تغيير فرمول شيميايى كانىها شده و ونسئ اكثر اين تغييرات در جهت تضعيف مقاومت سنگ عمل

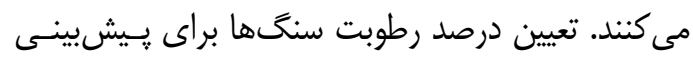

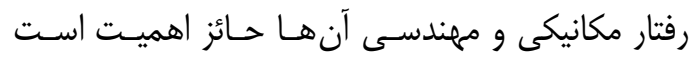

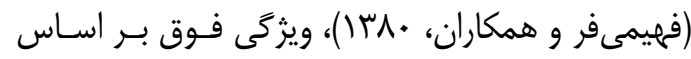

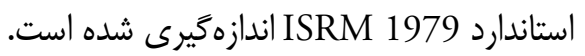

\section{- تعيين جِكَالى خشك و تخلخل كل}

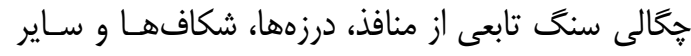

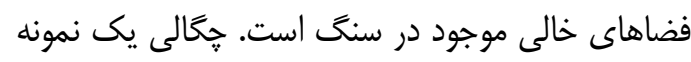

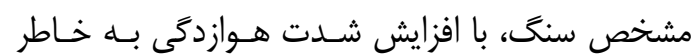
افزايش درز و ترك در سنگَ، تجزيه شـيميايى و تـورم

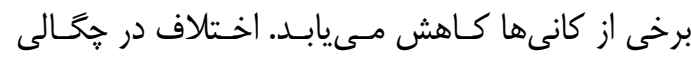

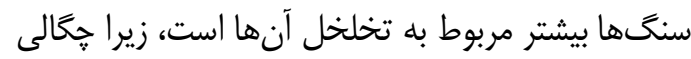
دانهاى اكثر كانىها نزديك به هم است و بدين ترتيـب مربن

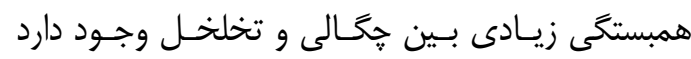

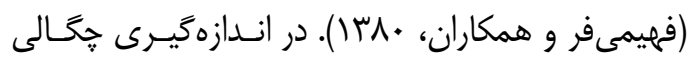

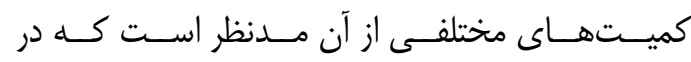

فيزيكى سنَ از جمله نرخ جذب آب، محتوى رطوبـت طبيعى، جِّالى خشك، تخلخل كل، ضريب اشباع سنى و ويثزى هاى دوامدارى از جمله، دوام در برابر وارفتخى،

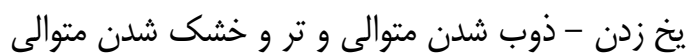
بررسى شدهاند.

\section{- نرخ جذب آب}

به دليل اين كه روشهاى اندازهزيرى نفوذيذيرى سنى در استانداردهاى موجود براى قطعات سنگى تحت فشار إنى

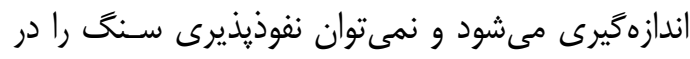

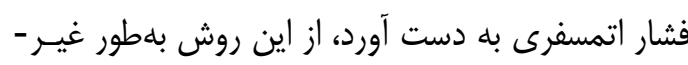
مستقيم براى اندازهيرى نرخ جذب آب اوليه (ميزان آب دئ جذب شده توسط منافذ مرتبط سنگ)، ثانويه (ميزان آب جذب شده به فضاهاى درون دانهاى سنَ) و ارتفاع زون

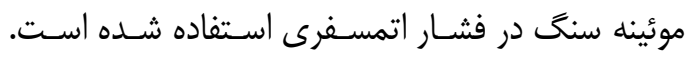
اساس آزمايش محاسبه نرخ جذب آب توسط يك نمونه سنگ به واسطه افزايش وزن آن درنتيجه جذب آب آب بـهـ صورت تابعى از زمان است، در حالتى كه فقط يك سطح

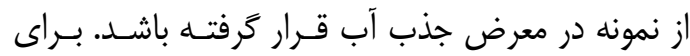

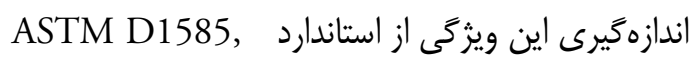
2004 استفاده شده است.

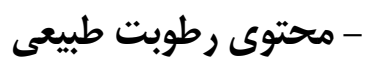
محتوى رطوبت يا محتـوى آب، نسـبت آب موجـود در

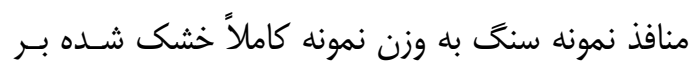

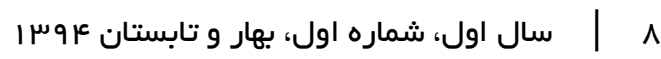


جوش مىباشد براى به دست آوردن ضريب اشباع سنى از استاندارد TS 699, 1987 استفاده شده است $\mathrm{S}=\left(\mathrm{W}_{\mathrm{c}}-\mathrm{W}_{\mathrm{d}}\right) /\left(\mathrm{W}_{\mathrm{b}}-\mathrm{W}_{\mathrm{d}}\right)$

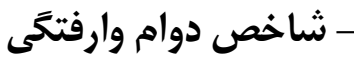

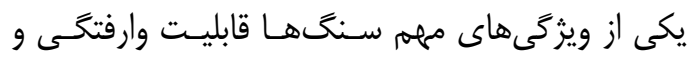

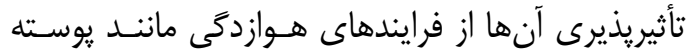

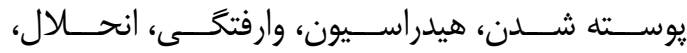

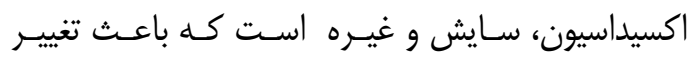

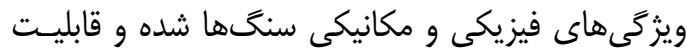

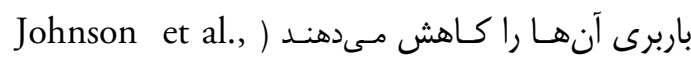

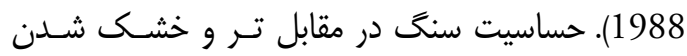

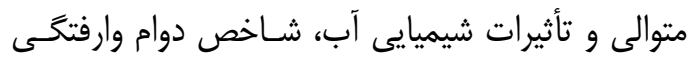

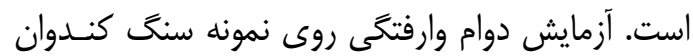
طبق استاندارد ASTM D 4644, 2004 و در دو مرحله

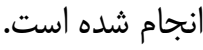

\section{- دوام در برابر يخ زدن و ذوب شدن متوالى}

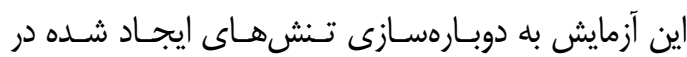

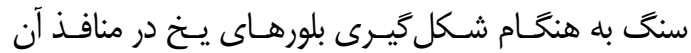
توجه دارد و بهطور كلى به وسيله تغييرات دما زير و بـالاى دئي

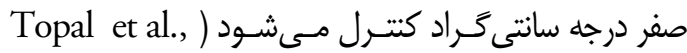

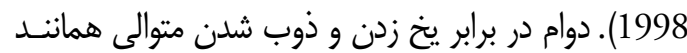

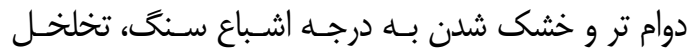

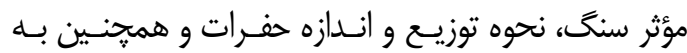

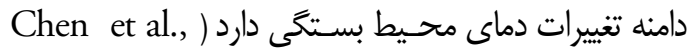

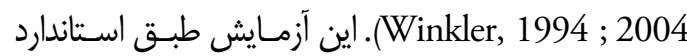
ASTM D 5312, 2004

\section{-دوام در برابر تر و خشك شدن متوالى}

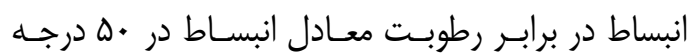

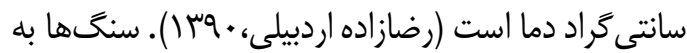

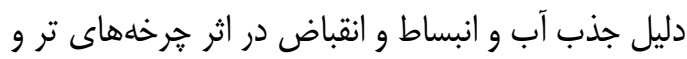

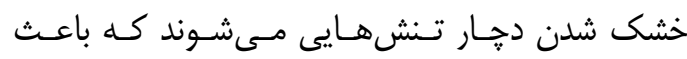

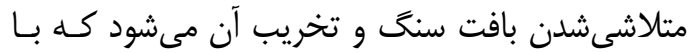
انجام اين آزمايش ميزان دوام سنگ در برابر تر و خشى تُش
طبقابندى هاى مهندسى طبق رابطه ا از پَّالى خشك

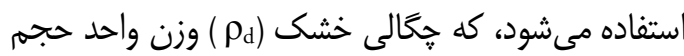

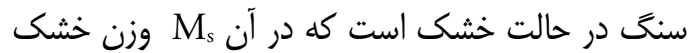

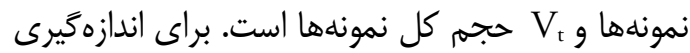

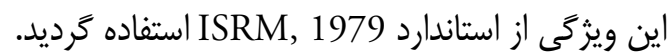
$\rho_{\mathrm{d}}=\mathrm{M}_{\mathrm{s}} / \mathrm{V}_{\mathrm{t}}$

تخلخل سنگ بستخى به شكل و توزيع ابعاد دانهها، سمتوسوى دانهها، درجه تراكم و سيمان شدگى دانههـا

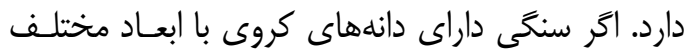

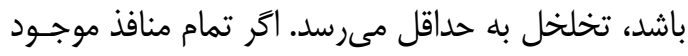

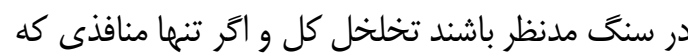

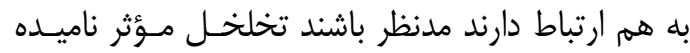
مى شود. تخلخل كل نسبت حجم كل منافذ موجود در

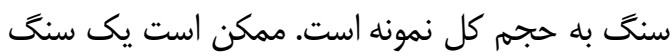
تخلخل كل قابلملاحظهاى داشـته باشـد درحـالى كـهـ قابليت كذردهى سيال آن به علت فقدان آنارئ ارتباط منافذ در

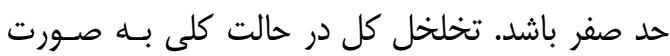

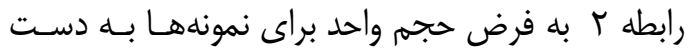

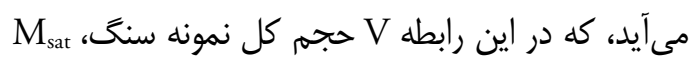

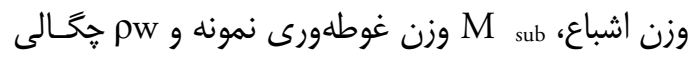

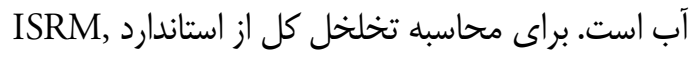
1979 استفاده شده است.

$\mathrm{V}=\left(\mathrm{M}_{\mathrm{sat}}-\mathrm{M}_{\mathrm{sub}}\right) / \rho_{\mathrm{w}}$

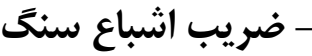

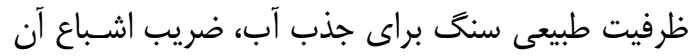

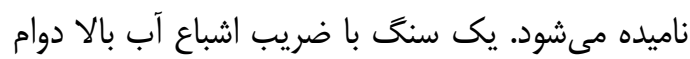
كمترى نسـبت بـه فراينــد ذوب و انجمـاد متـوالى دارد

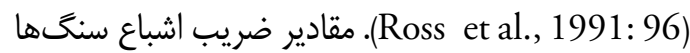

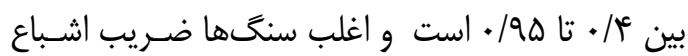

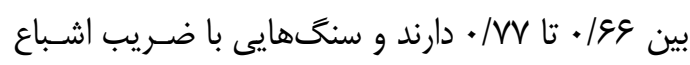

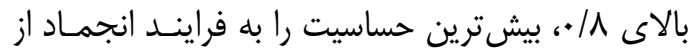

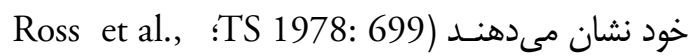

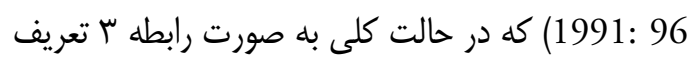

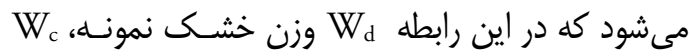

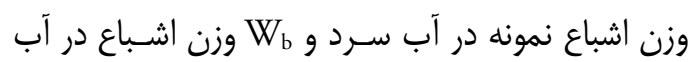


ديده مى شود كه سبب بافت غربالى "آ آنها كرديده است.

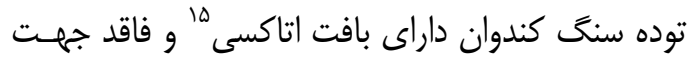

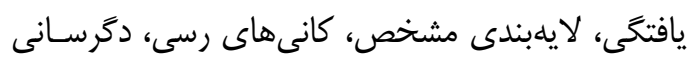

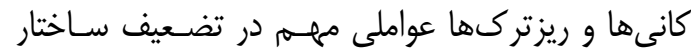

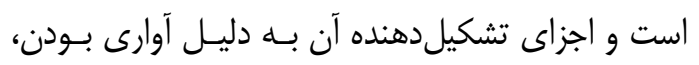

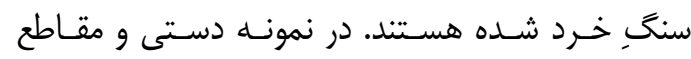
ميكروسكويى مىتوان طيف وسيعى از اندازه دانسهــا از

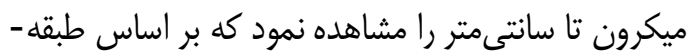

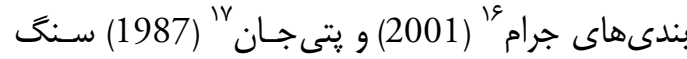

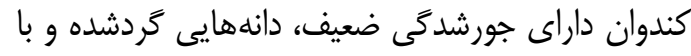

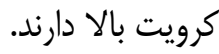

\section{צ- ع- آناليز يراش يرتو ايكس}

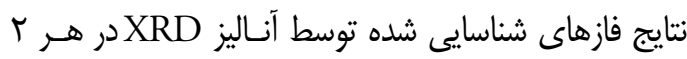

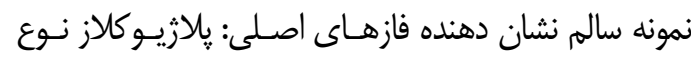

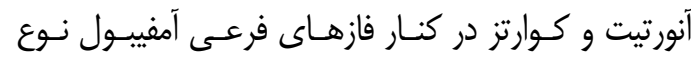

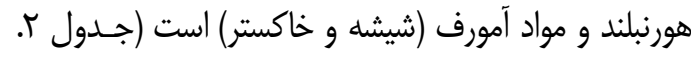

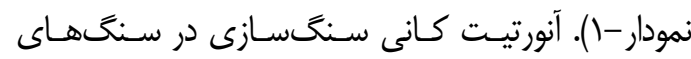

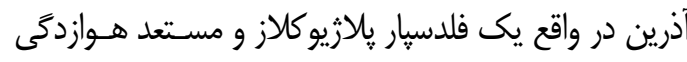

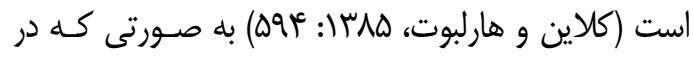

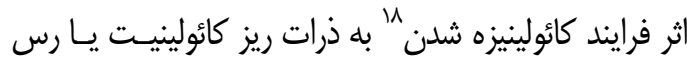
تبديل مىشوند، در نتيجه اين عمل عناصر قليـيـي موجـود فئين

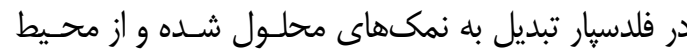

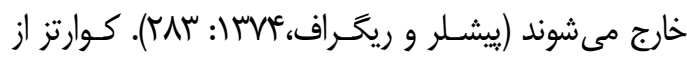
جمله كانىهـاى معمـول در سـنَّهـاى آذريـن و كـانى مقاومى در مقابل هوازدگى است.

تر كيب شيميايى هورنبلند به عنوان يك كانى سنى

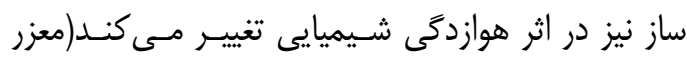

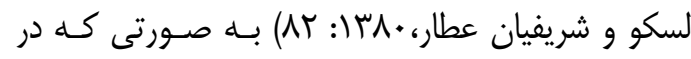

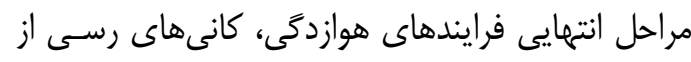

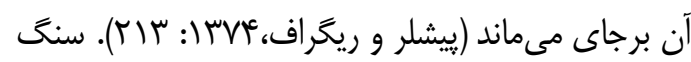
كندوان با توجه به قابليت هوازدمى شـيميايى و تبـديل

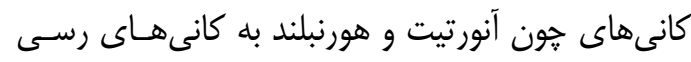
مستعد تخريب بالاست هراكه كانىهـاى رسى انسى انـرزى

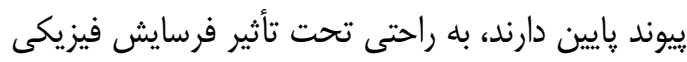

شدن متوالى تخمين زده مى شود. اين آزمايش در مـورد سنگ هايى مانند توف كه ضريب بالاى انبساط در بر برابـر

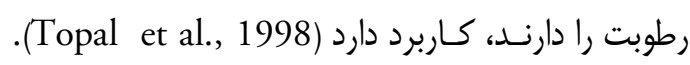
ASTM D براى اندازميرى اين ويزَّى از استاندارد 5313, 2004 استفاده شده است.

$$
\text { و- نتايج }
$$

צ-1 - ساختارشناسى و سنَش

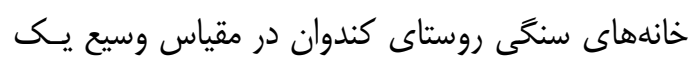

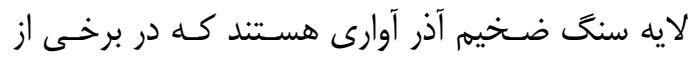

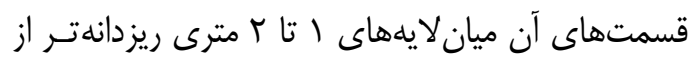

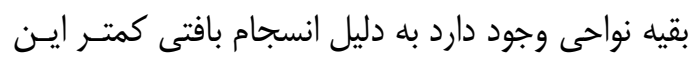

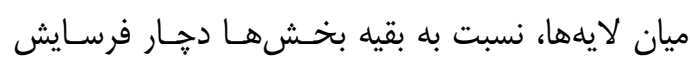

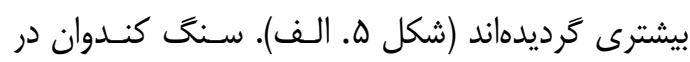

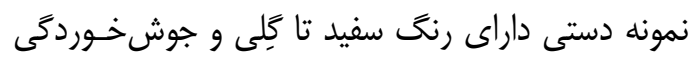

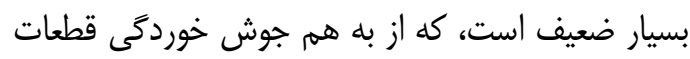

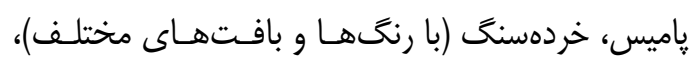

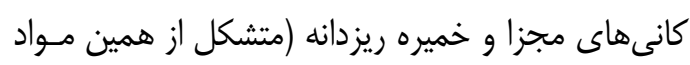

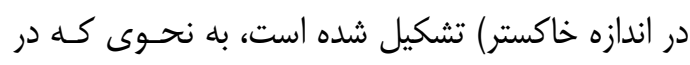

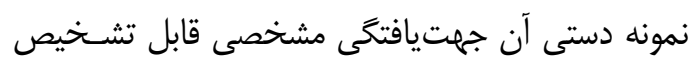
نيست (شكل ه. ب).

\section{צ-Y-Y - مطالعه مقاطع نازك ميكروسكويى}

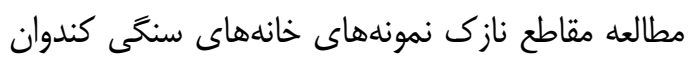

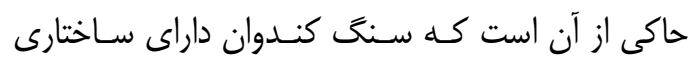

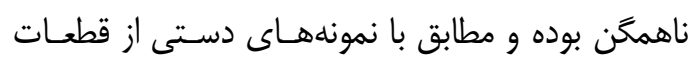

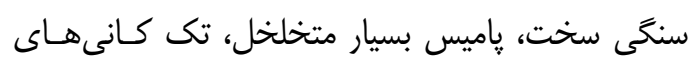

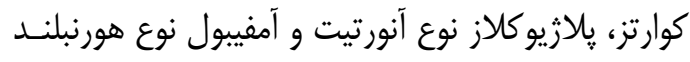

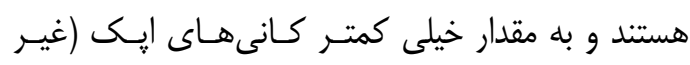

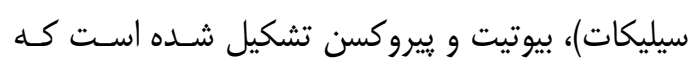

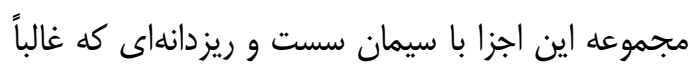

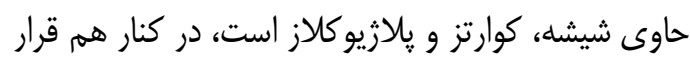

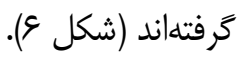

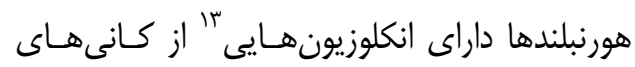

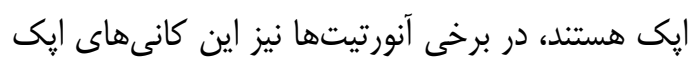


تحليل ساختارشناسى سنكَهاى آذرآوارى در معمارى صخرهكند روستاى تاريخى كندوان

\begin{tabular}{|c|c|c|c|c|}
\hline \multicolumn{5}{|c|}{ جدول.r نتايج دادههاى فاز شناسى يراش اشعه ايكس سنى كندوان } \\
\hline نمونه & فاز(ها) & نام كانى & فرمول & PDF Number \\
\hline \multirow{4}{*}{ S.1 } & \multirow{2}{*}{$\begin{array}{r}\text { Major } \\
\text { Phase(s) } \\
\end{array}$} & Anorthite & $(\mathrm{Ca}, \mathrm{Na})(\mathrm{SiAl})_{4} \mathrm{O}_{8}$ & $18-1220$ \\
\hline & & Quartz & $\mathrm{SiO}_{2}$ & $33-1161$ \\
\hline & \multirow{2}{*}{$\begin{array}{r}\text { Minor } \\
\text { Phase(s) }\end{array}$} & Hornblende & $\mathrm{Ca}_{2}(\mathrm{Fe} \cdot \mathrm{Mg})_{4} \mathrm{Al}\left(\mathrm{Si}_{7} \mathrm{Al}\right) \mathrm{O}_{22},(\mathrm{OH})_{2}$ & $45-1371$ \\
\hline & & Amorphous & - & - \\
\hline \multirow{4}{*}{ S.2 } & \multirow{2}{*}{$\begin{array}{r}\text { Major } \\
\text { Phase(s) }\end{array}$} & Anorthite & $(\mathrm{Ca}, \mathrm{Na})(\mathrm{SiAl})_{4} \mathrm{O}_{8}$ & $18-1220$ \\
\hline & & Quartz & $\mathrm{SiO}_{2}$ & 33-1161 \\
\hline & \multirow{2}{*}{$\begin{array}{r}\text { Minor } \\
\text { Phase(s) }\end{array}$} & Hornblende & $\mathrm{Ca}_{2}(\mathrm{Fe} \cdot \mathrm{Mg})_{4} \mathrm{Al}\left(\mathrm{Si}_{7} \mathrm{Al}\right) \mathrm{O}_{22},(\mathrm{OH})_{2}$ & $45-1371$ \\
\hline & & Amorphous & - & - \\
\hline
\end{tabular}
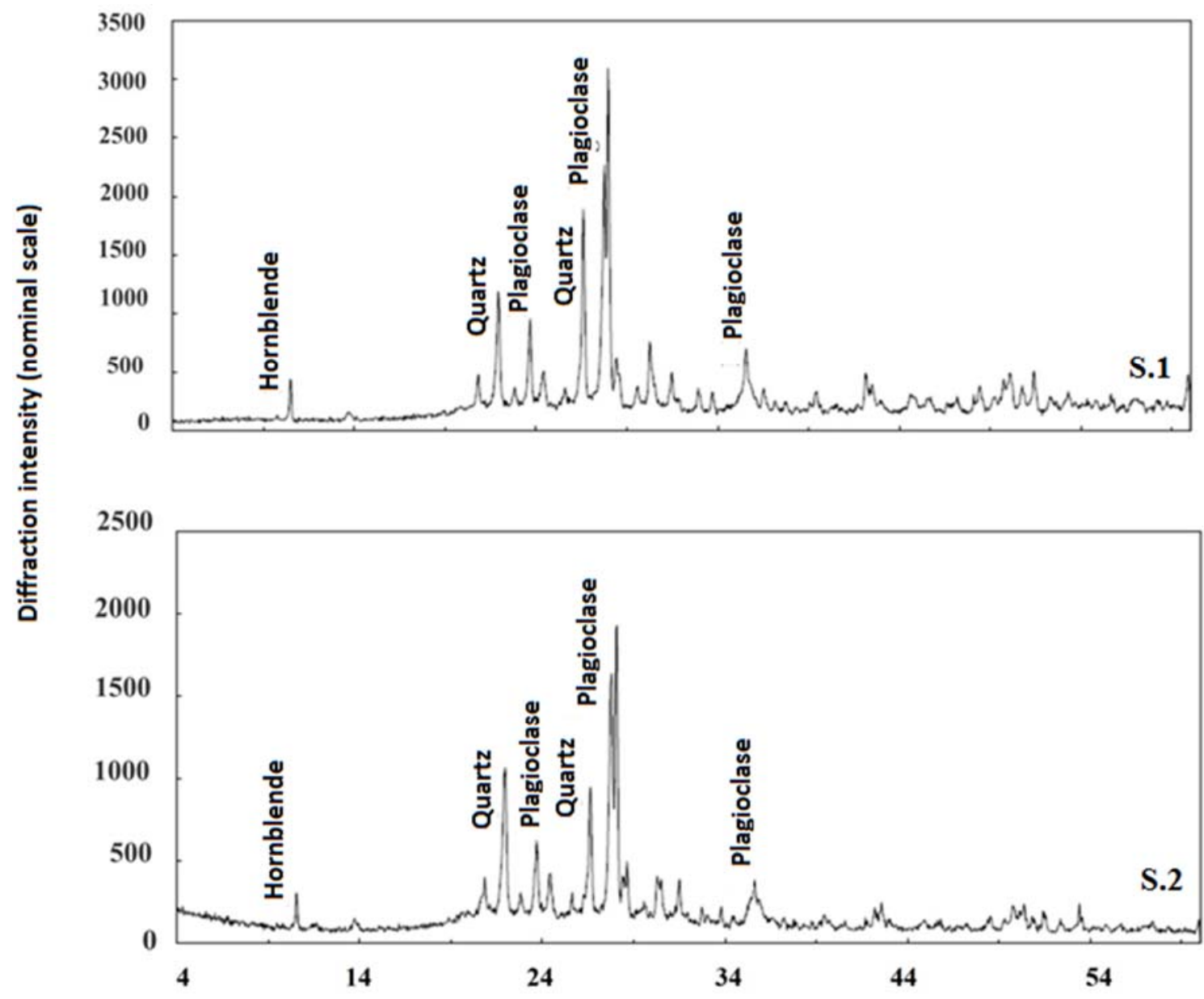

$2 \theta$ (diffraction angle of X-ray)

نمودار 1: نمودارهاى آناليز (XRD) سنگ سالم ايختيمبريت خانههاى صخرهاى روستاى كندوان

انجام كرفته و طبقهبنـدىهـاى سـنــهـاى آذر آوارى،

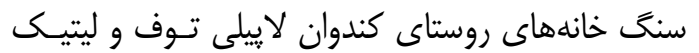
توف نامگذارى مىشوند ) Pettijohn, 1975: Fisher,

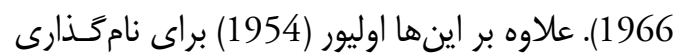

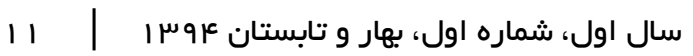

مثل آبهاى جارى قرار گرفته و از بستر جدا شده و

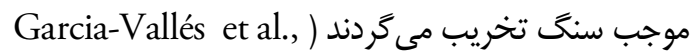

. (2003 با توجه به مطالعات ساختار شناسى و سنگشناسى 


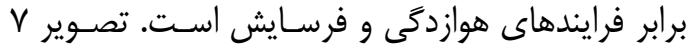

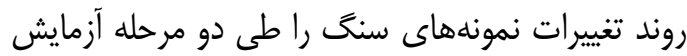

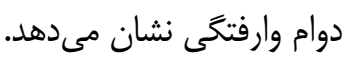

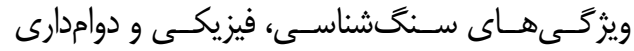

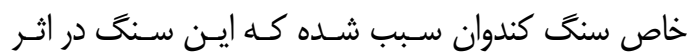

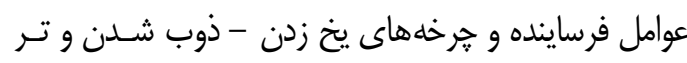
- خشك شدن متوالى ناشى از تغييرات آبوهــوايى روزانـهـ

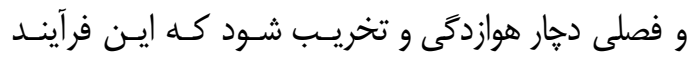

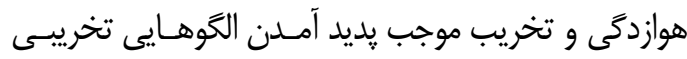

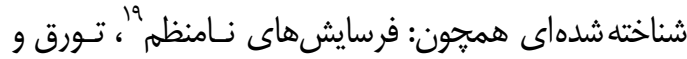

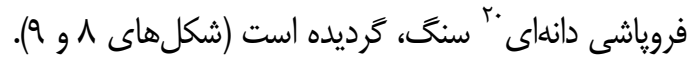

\section{V- نتيجلكيرى و ييشنهادات}

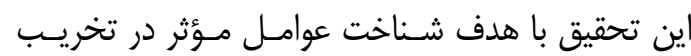

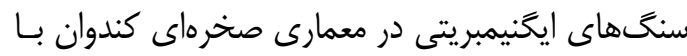

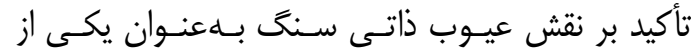

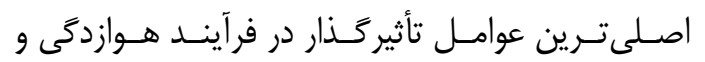

نهشتهاى لاييلى توف بـا بافت اتاكسى از اصـطلاح

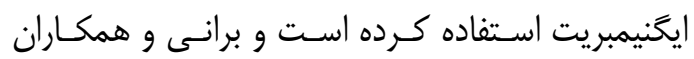

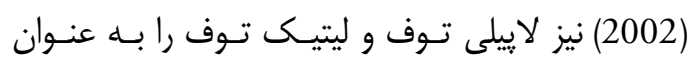

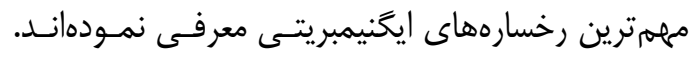

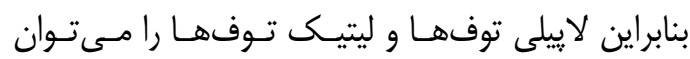

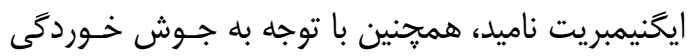

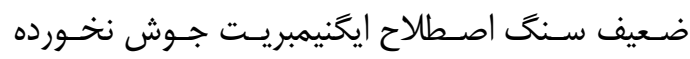
بهترين نام براى سنگ كندوان خواهد بود.

\section{צ-f - ويزَّى ها فيزيكى و دوامدارى}

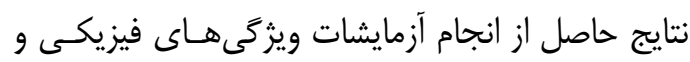

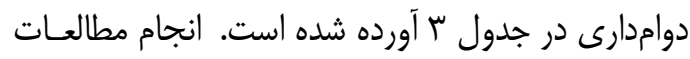
فيزيكى و دوامدارى امكان بررسى كيفـى سـنَّ را بـر

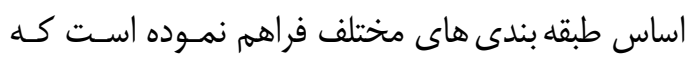
نتايج در جدول أ بيان شده است.

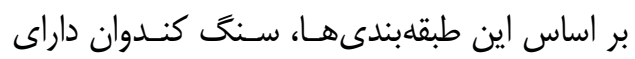

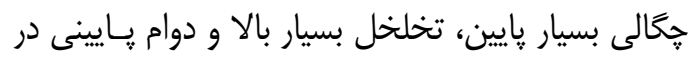

\begin{tabular}{|c|c|c|c|}
\hline \multicolumn{4}{|c|}{ جدول ب- نتايج حاصل از انجام أزمايشات ويثگى هاى فيزيكى و دوامدارى توده سنك كندوان(ماخذ: نكارندكان) } \\
\hline واحد & مقدار & روش أزمايش & كميت \\
\hline $\mathrm{mm} / \sqrt{\mathrm{S}}$ & $\cdot / \mu$ & ASTM D1585, 2004 & نرخ جذب أب اوليه \\
\hline $\mathrm{mm} / \sqrt{\mathrm{S}}$ & .1 .1 & ASTM D1585, 2004 & نرخ جذب ثانويه \\
\hline$\%$ & 落. & ISRM, 1979 & محتوى رطوبت طبيعى \\
\hline $\mathrm{gr} / \mathrm{cm}^{3}$ & $1 / \Delta$. & ISRM, 1979 & جكالى خشك \\
\hline$\%$ & $F \Delta-\Delta$ & ISRM, 1981 & تخلخل كل \\
\hline بدون واحد & $>\cdot / \Lambda$ & TS 699,1987 & ضريب اشباع سنك \\
\hline$\%$ & +1 & ASTM D 4644, 2004 & دوام وارفتكى مرحله اول \\
\hline$\%$ & vr & ASTM D 4644, 2004 & دوام وارفتكى مر حله دوم \\
\hline$\%$ & Gf & ASTM D 5312, 2004 & دوام يخ زنن و ذوب شدن متوالى \\
\hline$\%$ & $r$ & ASTM D 5313, 2004 & دوام تر و خشك شدن متوالى \\
\hline
\end{tabular}

\begin{tabular}{|c|c|c|}
\hline & \multicolumn{2}{|c|}{ جدول f|- وضعيت كيفى سنك كندوان براساس طبقهبندى هاى مختلف (ماخذ: نكارندكان) } \\
\hline توصيف & طبقلهبندىها & كميت \\
\hline 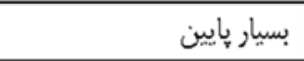 & Anon, 1979 & 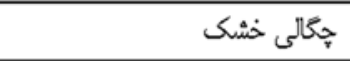 \\
\hline بسيار بالا & Anon, 1979 & تخلخل كل \\
\hline حساسيت بالا در برابر انجماد & TS 699, 1987 & 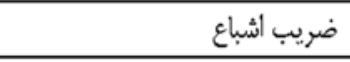 \\
\hline ضعيف & Franklin and Chandra, 1972 & شاخص دوام وارفتكى مرحله اول \\
\hline ضعيف & Gamble, 1971 & شاخص دوام وارفتكى مرحله دوم \\
\hline
\end{tabular}



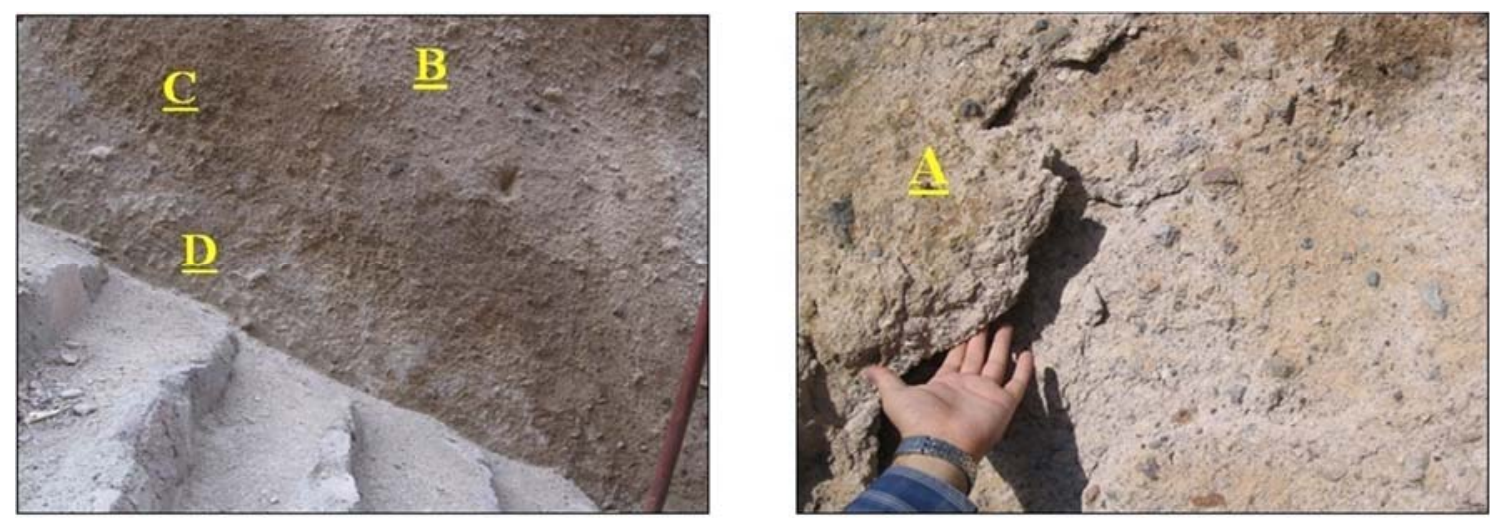

شكلهاى ^و ج: برخى كَونهاى شاخص آسيب سنخ در معمارى صخرماى كندوان. A) تورق شديد با بيش از هـ سانتىمتر جدايش از بستر

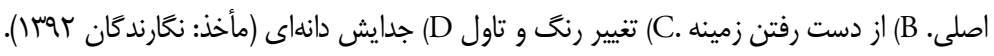

لحاظ ويزَّىهاى سنگَشناسى، سنگى ضعيف و مستعد

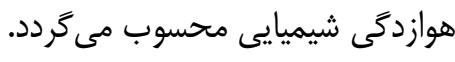

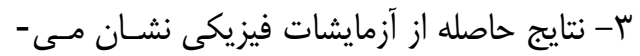

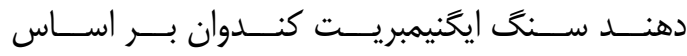

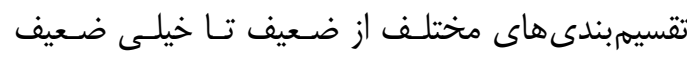

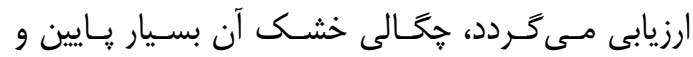
تخلخل كلىاش بسيار بالاست. اين ميزان تخلخل بالاى

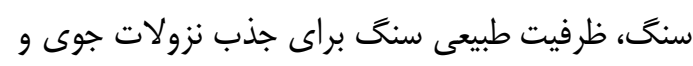

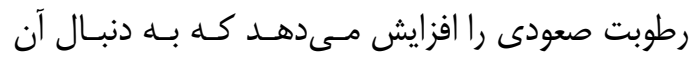
تخريب و فرسودمى سنى نيز افزايش مى إيايد.

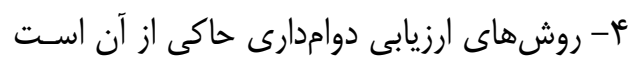

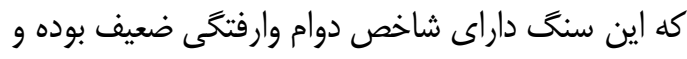

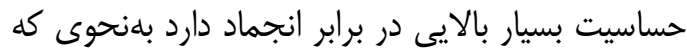

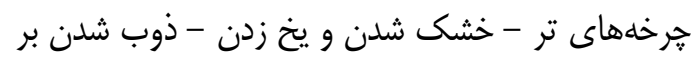

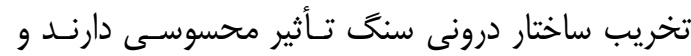

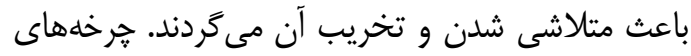

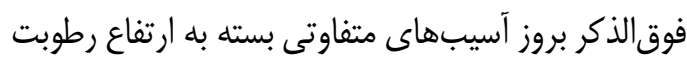

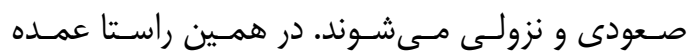
تخريبهايى كه بلهورت يودرى شدن و جدايش دانهاى

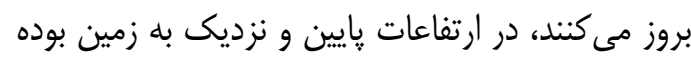
و در ارتفاعات بالا با آسيب تورق شديد و جدايش قطعات برديات بزرى سنَ مواجه هستيه، كه اين امر حساست سـنَ

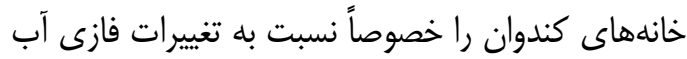
نشان مى دهد. ه- امكان كـاهش تخريـب و زوال در سـازههـاى

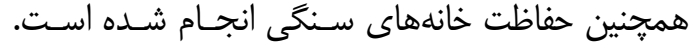

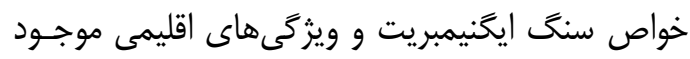
در دامنه سهند حاكى از آن اسـت كـه در كنـار عوامـل محيطى، عيوب ذاتى سـنَّ نقـش اساسـى در توسعله

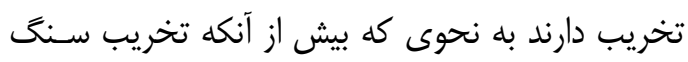
كندوان به شرايط محيطى ارتباط يابد، مربوط به ساختار و ساختمان سنگ ايخنيمبريت است. ا - نتايج بررسى هاى هواشناسى منطقه حاكى از آن آن است كه متوسط קرخه تر و خشـك شـدن سـالانه

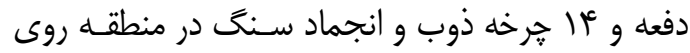
مى دهد و در ماههاى فروردين، ارديبهشت، آبان و آذرماه

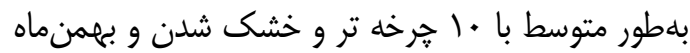

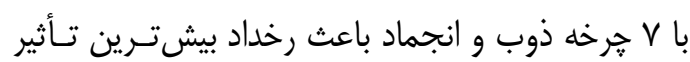
مخرب فيزيكى بر خانههاى سنخى روستا مى شوند. لازم

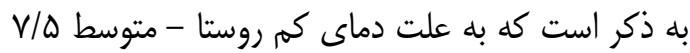

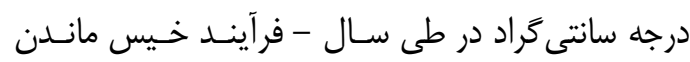

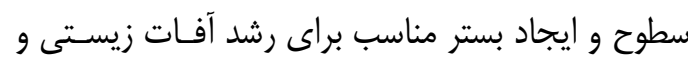
هوازدمى شيميايى و تخريب سطحى در تمام طول سال

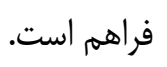

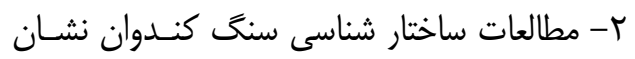

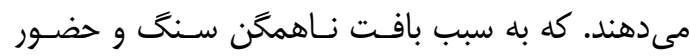

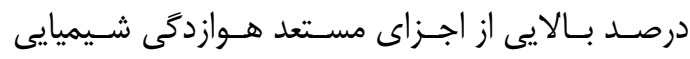

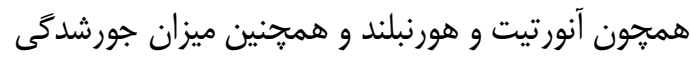

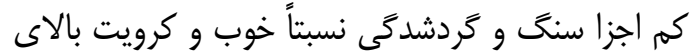

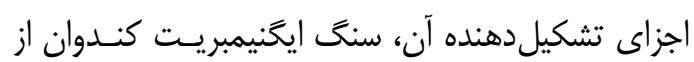


يزوهش عمران راهور، آزمايشحاه مكانيك خاك دانشكده

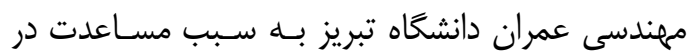

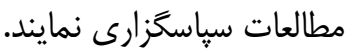

1. Decay

2. Weathering

3. Rock-Cut Architecture

4. Diagnostic

5. Durability

6. Inherent Vice

7. Ignimbrite

8. Local Climate

9. Emberger

10. Thin Section Petrography

11. X-ray diffraction

12. Capillary

13. Inclusion

14. Sieve

15. Ataxia

16. Jerram

17. Pettijohn

18. Kaolinisation

19. Differential Erosion

20. Granular disintegration

\section{منابع فارسى}

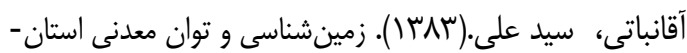

هاى آذربايجان شرقى و اردبيل. جغرافيا. رشد آموزش زمين - زاني

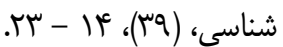

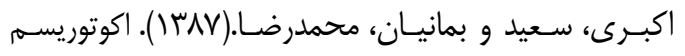

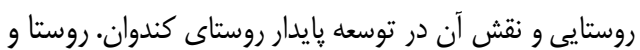

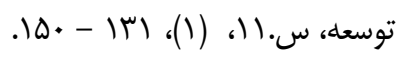

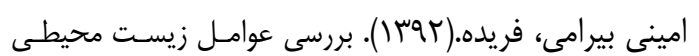

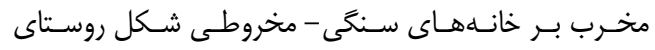

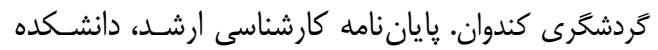

$$
\text { علوم طبيعى، دانشكاه تبريز. }
$$

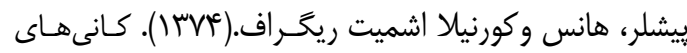

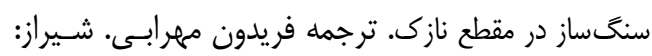

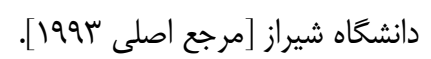

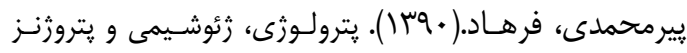
سنخَهاى آتشفشانى شرق و جنوب شرق آتشفشان سهند بـاــا
صخرهاى روستاى كندوان به واسـطه حساسـيت بسـيار

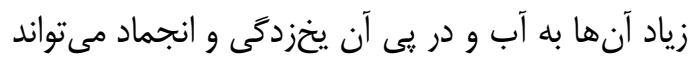

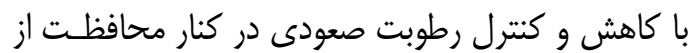
سطوح بيرونى در مقابل عوامل جوى حاصـل شـود. امـاــا

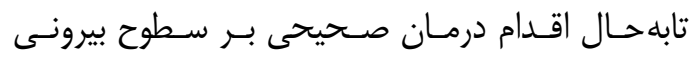
خانهاى سنكى روستاى كندوان صورت نكخرفته است و

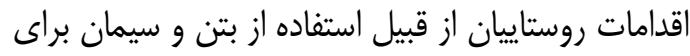

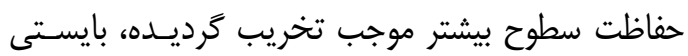

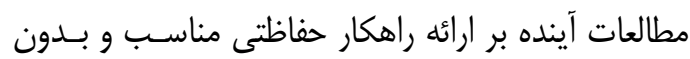

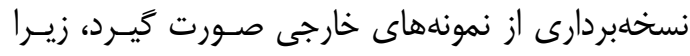
شرايط اقليمى و محيط قراركيرى كندوان در كنار استفاده

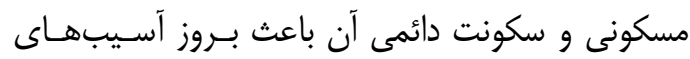

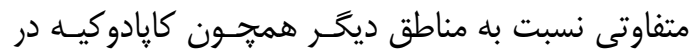
تر كيه ترديده است. ه- خواص ذاتى ضـعيف تـوف كنـدوان در كنـار

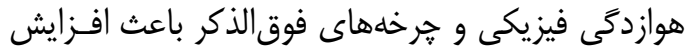

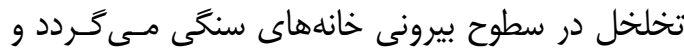

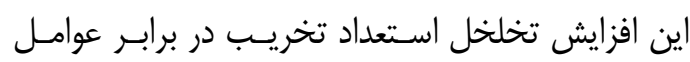

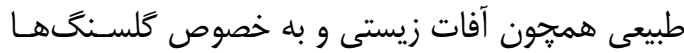

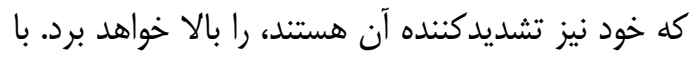

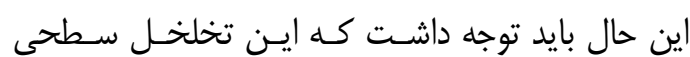

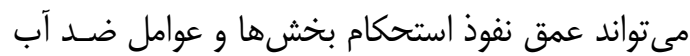

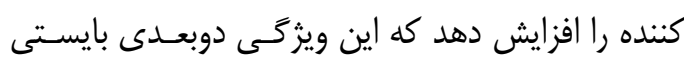
مورد توجه حفاظت كران قرار كيرد.

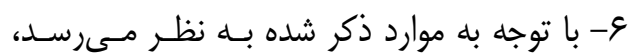
برنامه كلان مديريت روستاى كندوان در بخش حفاظت

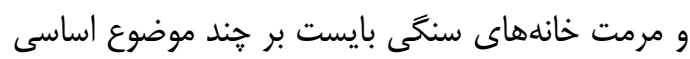
از قبيل : تعيين اولويتهاى حفاظت سطحى و سـازهاى،

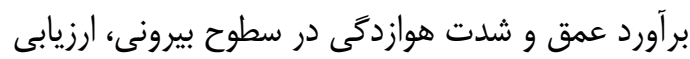

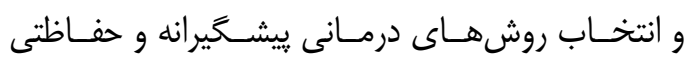

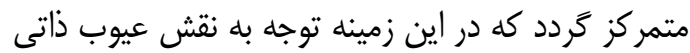

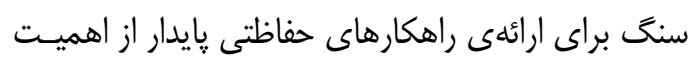

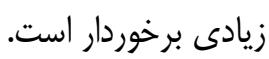

\section{سباسگزارى}

نغارندكان بر خود لازم مى دانند از مهندس سعيداريد مهريار،

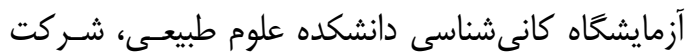

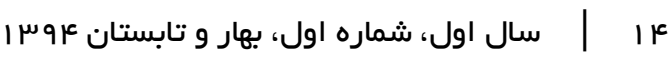




$$
\begin{aligned}
& \text { تمبران: مركز نشر دانشكاهى. } \\
& \text { كرجى مهلبانى، يوسف و سنائى، الميرا.(1/ (1). معمارى همساز }
\end{aligned}
$$

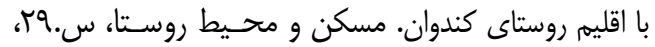

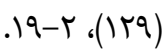

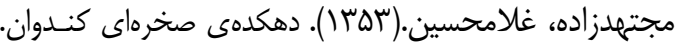

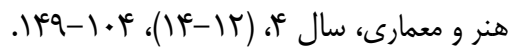

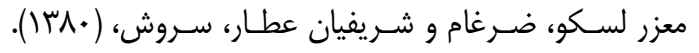

$$
\begin{aligned}
& \text { كانى شناسى نورى. مشهل: وازٔكان خرد. }
\end{aligned}
$$

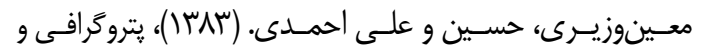

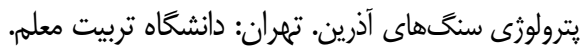

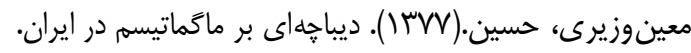

$$
\begin{aligned}
& \text { تهران: دانشخاه تربيت معلم. } \\
& \text { كندوان، تبريز: هنر اول. }
\end{aligned}
$$

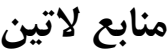

Anon. (1979). Classification of rocks and soils for engineering geological mapping, part. 1 Rocks and soils material. Bulletin International Association Engineering Geology, No. 19, 71-364.

ASTM. (2004). Standard Test Method for Evaluation of Durability of Rock for Erosion Control under Freezing \& Thawing Conditions (D5312). Annual Book of ASTM Standards, Vol. 04. 08, 894 - 998.

ASTM. (2004). Standard Test Method for Evaluation of Durability of Rock for Erosion Control under Wetting \& Drying Conditions (D5313). Annual Book of ASTM Standards, Vol. 04. 08, $890-893$.

ASTM (2004). Standard Test Method for Slake Durability of Shales and Similar Weak Rocks (D 4644). Annual Book of ASTM Stand ards, Vol. 04.08.

ASTM. (2004). Standard Test Method for Measurement Rate of Absorption of Water by Hydraulic-Cement Concretes (D 1585). Annual Book of

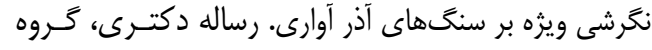
زمين شناسى، دانشكده علوم طبيعى، دانشخاه تبريز.

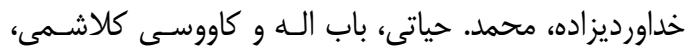

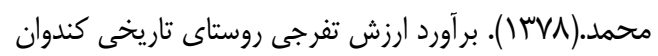

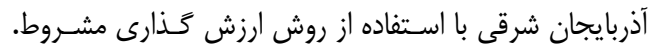

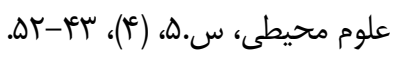

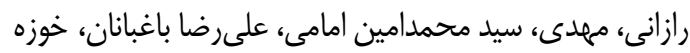

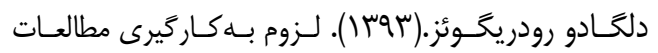

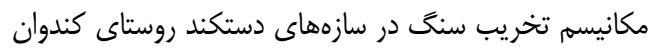

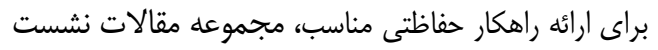

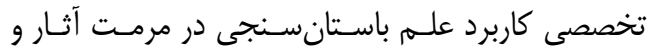

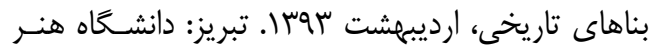

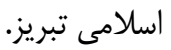
رضازاده اردبيلى، مجتبى.(•وج"). مرمت آثار معمارى، شناخت،

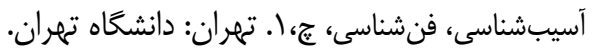

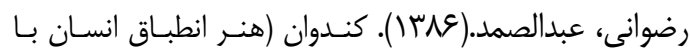

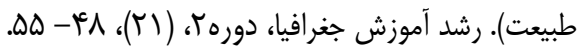

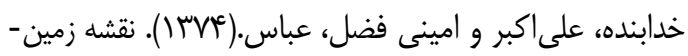

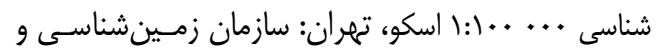
اكتشافات معدنى كشور.

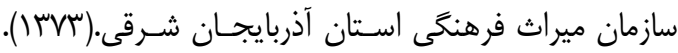

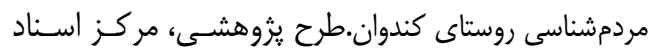

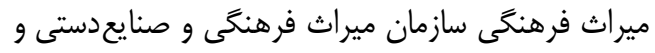
كرَدشَّى استان آذربايجان شرقى.

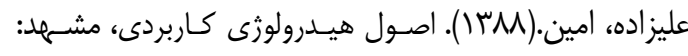

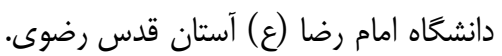

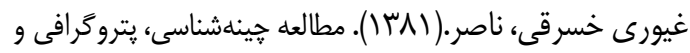

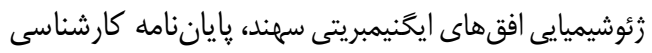
ارشد، دانشخاه تربيت معله تهران.

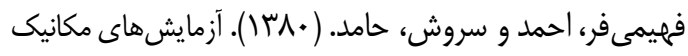

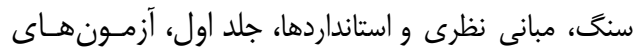
آزمايشگاهى تهران : دانشخاه امير كبير.

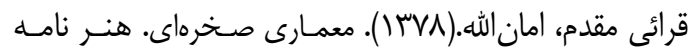

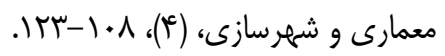

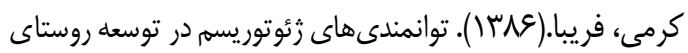

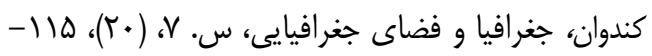
.

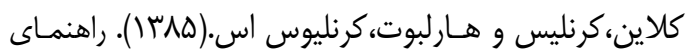

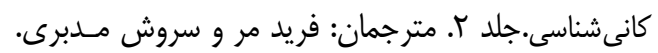


ASTM Standards, Vol. 04. 08, 948-955.

ASTM. (2009). Standard Guide for Petrographic Examination of Dimension Stone (C 1721). Book of Standards, Volume: 04. 07.

Branney, M. J. Kokelaar, B. P. (2002). Pyroclastic Density Currents and the Sedimentation of Ignimbrites. London, Geological Society of London.

Chen, T. C. Yeung, M. R \& Mori, N. (2004). Effect of water saturation on deterioration of welded tuff due to freeze-thaw action. Cold Regions Science and Technology, 38 (2), 127-136.

Doehne, E \& Price, C. A. (2010). Stone conservation: an overview of current research. Getty Publications.

Dreesen, R. \& Dusar, M. (2004). Historical building stones in the province of Limburg (NE Belgium): role of petrography in provenance and $d u$ rability assessment. Materials Characterization, 56, 273-287

Emberger, L. (1930). La vegetation de la region mediterraneenne, Essai d'une classification des groupments vegetaux. Rev. Gen. Bot. 42: 641662, 705-721.

Fisher, R. V. (1966) Mechanism of deposition from Pyroclastic flows. Amer. J. Sci. 264, 350363.

Fookes, P. G. Gourley, C. S \& Ihikere, C. (1982). Rock Weathering in engineering time. Quarterly Journal of Engineering Geology, Vol. 21, 33-57.

Franklin, J. A. \& Chandra, R. (1972). The slake durability index, Int. J. Rock. Mech. Min. Sci, 9, 325-342.

Garcia-Vallés, M, Topal, T. Vendrell-Saz, M. (2003). Lithenic growth as a factor in the physical deterioration or protection of Cappadocia monuments. Environmental Geology 43, 776-781.

Google Earth., (2013). "Kandovan,” 609968. 47 m $\mathrm{E}$ and $4183852.93 \mathrm{~m} \mathrm{~N}$. Google Earth. January 9, 2013. January 18, 2014

International Society for Rock Mechanics. (1979).
Suggested Methods for Determining Water Content, Porosity, Absorption and related properties and swelling and slake-durability. International Journal of Rock Mechanics and Mining Sciences, 36, 139-153.

Jerram, D. A. (2001). Visual comparators for degree of grain-size sorting in two and three-dimension. Computers and Geosciences, 27, 485 - 489.

Johnson, R. B \& Degraff, J. V. (1988). Principles of Engineering Geology, John Wiley and Sons, USA, 497 Pp.

Oliver, R. L. (1954). Welded tuffs in the Borrowdale Volcanic Series, English Lake District, with a note on similar rocks in Wales. Geological Magazine, 91: $473-83$.

Pettijohn, F. J. (1975). Sedimentry Rocks, Harper $\&$ Row. New York.

Rodriguez, J. D. (2007). Conservation of stone monuments. from diagnostic to practice. Minbar Al Jamiaa n 7, Actes de la RIPAM (2005), Meknès, Maroc, pp. 287-295.

Ross, K., Hart, D., \& Butlin, R. N. (1991). Durability tests for natural building stone. In Durability of building materials and components. Proceedings of the Fifth International Conference held in Brighton, UK, 7-9 November 1990 (pp. 97-111). Chapman and Hall Ltd.; E. \&FN Spon Ltd.

Topal, T. \& Doyuran, V. (1998). Analyses of deterioration of the Cappadocian tuff, Turkey. Environmental Geology, 34 (1), 5-20.

TS699. (1987). Tabii Yapi Tas lari - Muayene ve Deney metodlari, (Methods of testing for natural building stones) Turk Standartları Enstitusu, Ankara (in Turkish).

Verges-Belmin, V., ed. (2008). Illustrated Glossary on Stone Deterioration Patterns. English-French ed. Paris: ICOMOS \& ISCS (International Scientific Committee for Stone).

Winkler, E. M. (1994). Stone in Architecture: Properties, Durability. 3rd ed. Berlin and NY: Springer-Verlag. 